\title{
Plankton community structure and carbon cycling on the western coast of Greenland during and after the sedimentation of a diatom bloom
}

\author{
Torkel Gissel Nielsen ${ }^{1, *}$, Benni Hansen ${ }^{2}$ \\ 'National Environmental Research Institute, Department of Marine Ecology and Microbiology, Frederiksborgvej 399, \\ PO Box 358, DK-4000 Roskilde, Denmark \\ ${ }^{2}$ Roskilde University, Institute I, Life Sciences and Chemistry, PO Box 260, DK-4000 Roskilde, Denmark
}

\begin{abstract}
Pelagic food web structure and carbon dynamics were studied in Disko Bay, western Greenland, following the breakup of the sea ice in June-July 1992. Disko Bay was influenced by meltwater, and calm sunny weather heated the surface water from 0 to $6^{\circ} \mathrm{C}$. Initially a diatom bloom was present throughout the photic zone. Due to nutrient depletion, and deepening of the surface layer, the bloom left the photic zone. Active bacterioplankton was observed from the first sampling. Bacterial production increased from a few percent to one-third of the primary production after the sedimentation of the bloom. The grazing impact by the copepod community was assessed by 2 independent methods. The gut fluorescence method and the egg production method resulted in copepod grazing estimates of about 80 and $45 \%$ of the primary production $\mathrm{d}^{-1}$, respectively. Carbon budget considerations showed that the estimated protozooplankton grazing impact was comparable, or higher, than grazing by the Calanus spp. dominated copepod community. The observed importance of Arctic bacteria and protozooplankton stress that high latitude pelagic food webs potentially have the same trophic complexity as low latitude pelagic ecosystems.
\end{abstract}

KEY WORDS: Arctic pelagic food web Copepods P Protozoa - Bacteria - Grazing impact - Carbon budgets

\section{INTRODUCTION}

The importance of bacteria and protozoans in the pelagic ecosystems has been documented during the last decade (reviewed by Fenchel 1988). In Antarctica, bacteria and the microbial food web are now incorporated into the pelagic food web (e.g. Azam et al. 1991). In the Arctic, however, most attention is still given to the large herbivorous copepods, which often form the bulk of the heterotrophic planktonic biomass. The literature contains much information on ecology and population dynamics of Arctic copepods, especially the Calanus spp. (reviewed by Smith \& Schnack-Schiel 1990). Relatively little effort has been put into studies of the smaller heterotrophic components, and data sets

•E-mail: hmtgn@dmu.dk that allow comparison of standing stock and grazing impact of meso- and protozooplankton in the Arctic pelagic ecosystem are still lacking.

Pomeroy \& Deibel (1986) questioned the importance of bacteria in cold water ecosystems. Data from the spring bloom in Newfoundland (Canada) coastal waters indicated that bacterial activity was inhibited at temperatures below $4^{\circ} \mathrm{C}$. They concluded that bacteria was less important in cold than in temperate waters. They suggested that a larger fraction of the primary production would therefore find its way directly to the metazoan consumers and to the benthic communities. However, Thingstad \& Martinussen (1991) pointed out that the summer temperature in the Arctic is not very different from temperatures during the spring bloom in temperate waters, where the annual peaks in bacterial production are often observed (Lancelot \& Billen 1984, Kuosa \& Kivi 1989). 
Studies of bacterial production in Arctic pelagic ecosystems have also shown that generation times and activity of the bacterioplankton are comparable to the rates obtained in low latitude ecosystems (e.g. Andersen 1988, Thingstad \& Martinussen 1991). Despite this evidence, knowledge about the fate of bacterial production and the dynamics of the succeeding protozoan links in the food chain is limited.

Information on abundance, biomass and species composition of Arctic pelagic protists is available for heterotrophic nanoflagellates (Thomsen 1982, Andersen 1988), ciliates (Paranjape 1987, Putt 1990) and heterotrophic dinoflagellates (Lessard 1991). These investigations illustrate that a diverse microbial community is present in the Arctic as in Antarctica (e.g. Garrison et al. 1993) and that microbial abundances are comparable with those in temperate ecosystems (Taniguchi 1984, reviewed by Pierce \& Turner 1992). To our knowledge, the only simultaneous measurements of all microbial loop components in the Arctic were carried out by Andersen (1988) during a case study in the North Bering/Chukchi sea. He concluded that the microbial loop played an important role in the carbon flow at stations where pico- and nanophytoplankton dominated. At these stations approximately $75 \%$ of the primary production was processed by the microbial loop, whereas only about $5 \%$ was processed by the microbial loop at diatom-dominated stations. Unfortunately, the study lacks information on the grazing potential and the mesozooplankton biomass, which previously was considered the most important pathway.

The annual phytoplankton succession in Arctic pelagic ecosystems without persistent fast ice is similar to succession in temperate ecosystems (Smith \& Sakshaug 1990): after the spring bloom has depleted the surface water of nutrients, the primary production is dependent on nutrients remineralized in the surface water until the breakdown of stratification during the fall. An important difference between the 2 ecosystems is the large population of overwintering copepods, with a significant potential for grazing on the spring bloom (e.g. Tande 1991).

Here we present measurements of the standing stocks and the carbon flow within both the classical and the microbial food web along the west coast of Greenland. Our aim is to evaluate the role of the microbial food web in the carbon cycling of an Arctic ecosystem.

\section{MATERIALS AND METHODS}

Study site. This investigation was conducted from 22 June to 6 July 1992, approximately 1 nautical mile off Godhavn harbour (69. $\left.15^{\prime} \mathrm{N}, 53^{\circ} 33^{\prime} \mathrm{W}\right)$ at $200 \mathrm{~m}$ depth in Disko Bay at the west coast of Greenland
(Fig. 1). During the investigation the station was visited on 10 occasions by the RV 'Porsild' (Arctic Station, University of Copenhagen).

Sampling. Sampling was conducted around local noon. Vertical profiles of salinity, temperature and fluorescence were obtained from the surface to $30 \mathrm{~m}$. Temperature and salinity were recorded using a temperature and salinity (LF 191, Mobro Instr.) probe, and chlorophyll a (chl a) fluorescence was measured with a Hardt fluorometer. Light attenuation was estimated from Secci disk depth. From the vertical distribution of temperature, salinity and fluorescence, 5 to 6 depths in the upper $30 \mathrm{~m}$ were selected for chemical and biological measurements.

Nutrients. Duplicate samples for the determination of nutrient concentration $\left(\mathrm{NO}_{2}{ }^{-}, \mathrm{NO}_{3}{ }^{-}, \mathrm{PO}_{4}{ }^{3-}, \mathrm{SiO}_{4}{ }^{3-}\right)$ were fixed by 2 drops of chloroform and deep frozen. After arrival at the laboratory, the nutrient concentration was measured on an automatic nutrient analyser (Dansk Havteknik) following Grasshoff (1976).

Chlorophyll a. Samples of 1 to 21 for chl a measurements were placed in the dark and within $3 \mathrm{~h}$ after collection filtered onto $\mathrm{GF} / \mathrm{F}$ filters, extracted in $96 \%$ ethanol (Jespersen \& Christoffersen 1987) and measured spectrophotometrically (Strickland \& Parsons 1968). The in situ fluorometer measurements were calibrated against the spectrophotometrically determined chlorophyll content in the water samples, and a linear regression was conducted $\left(\mathrm{r}^{2}=0.7, \mathrm{n}=56\right)$. The chl $a$ fraction $>11 \mu \mathrm{m}$ was measured as the concentration of $\mathrm{chl} a$ in the water after gentle filtration through $11 \mu \mathrm{m}$ Nitex screen. The phytoplankton carbon content was estimated from volume measurements using an inverted microscope and a conversion factor of $0.12 \mathrm{pg} \mathrm{C}$ $\mu \mathrm{m}^{-3}$ (Edler 1979). In addition to the absorption measurements required for the determination of $\mathrm{chl} a_{\text {, }} \mathrm{ab}$ sorption was also measured at $480 \mathrm{~nm}$. Changes in the ratio of absorption of $480: 665 \mathrm{~nm}$ indicate the nutritional status of the phytoplankton cells, where values above 2 indicate that the phytoplankton is nutrient limited (Heath et al. 1990).

Primary production. Primary production was measured in situ with the ${ }^{14} \mathrm{C}$ method. Water samples from the various depths were incubated for $2 \mathrm{~h}$ around noon in 2 light and 1 dark Jena bottles $(100 \mathrm{ml})$, and $4 \mu \mathrm{Ci}$ $\mathrm{H}^{14} \mathrm{CO}_{3}{ }^{-}$(International Agency for ${ }^{14} \mathrm{C}$ Determination) was added to each bottle. After the incubation the bottles were kept dark, and filtration began within $1 \mathrm{~h}$. The entire contents of each bottle were pressurefiltered ( $<100 \mathrm{~mm} \mathrm{Hg}$ ) through $25 \mathrm{~mm} \mathrm{GF/F}$ filters. The filters were placed in scintillation vials, inorganic ${ }^{14} \mathrm{C}$ was removed by adding $200 \mu l$ of $1 \mathrm{~N} \mathrm{HCl}$. and the samples were kept frozen until counting. Excess inorganic ${ }^{14} \mathrm{C}$ was removed by applying a flow of air into the vials shortly before scintillation fluid was added. 

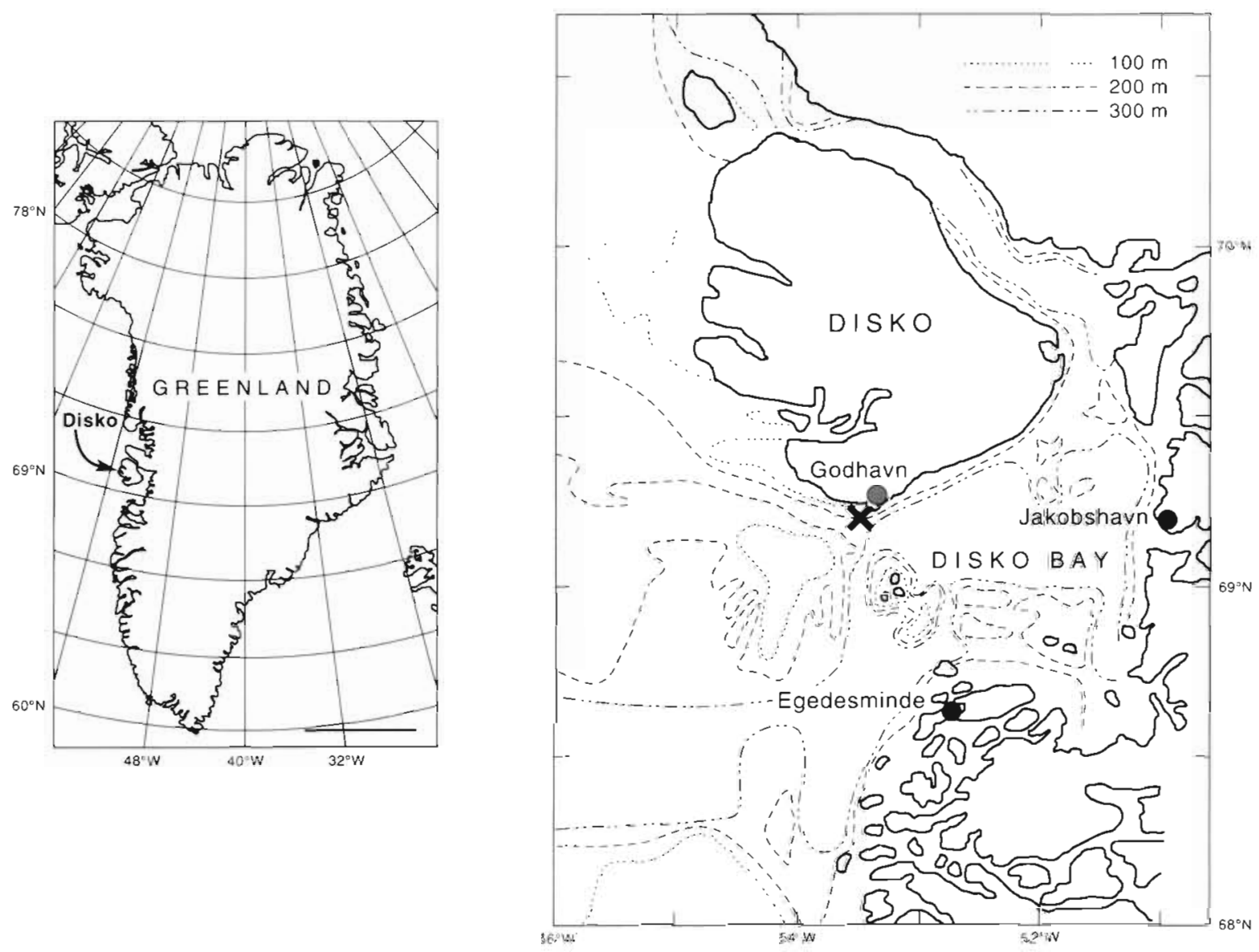

Fig. 1. Map showing approximate position of the station investigated

Filtercount (Packard Instr.) was added to the filters, and incorporated ${ }^{14} \mathrm{C}$ was measured by liquid scintillation counting (LKB Vallac 1219 Rackbeta) with the external standard method.

The total $\mathrm{CO}_{2}$ was assumed to be $2.1 \mu \mathrm{M}$ (Richardson 1991). Daily primary production was calculated by multiplying with a light factor: total daily insolation divided by insolation during the incubation period (e.g. Vadstein et al. 1989, Harrison et al. 1991). Light measurements were performed every 30 min with a Solar Radiation Sensor 2770 (300 to $2500 \mathrm{~nm}$ ) (Aanderaa Instr., Bergen, Norway) situated at the Arctic Station, Godhavn. Carbon fixation is presented after subtracting the dark fixation values, and without subtracting any respiration. The daily primary production per $\mathrm{m}^{2}$ was calculated by trapezoidal integration over the depth strata down to $32 \mathrm{~m}$ (Nielsen \& Bresta 1984).

Bacteria. Bacteria were counted using the acridine orange technique (Hobbie et al. 1977). At least 400 cells were enumerated on each filter using an Olympus $\mathrm{BH}-2$ epifluoresence microscope. The volume was estimated from length and width measurements of 50 cells per filter and converted to carbon using a conversion factor of $0.35 \mathrm{pg} \mathrm{C} \mathrm{mm}^{-3}$ (Bjørnsen 1986).
Bacterial production was measured by incorporation of ${ }^{3} \mathrm{H}$-thymidine (Fuhrman \& Azam 1980). Immediately after sampling, triplicate samples $(10 \mathrm{ml})$ were incubated with $5 \mathrm{nM}$ methyl ${ }^{3} \mathrm{H}$-thymidine $\left(20 \mu \mathrm{Ci} \mathrm{nmol}^{-1}\right.$, New England Nuclear) for $1 \mathrm{~h}$ at in situ temperature. Blanks were prepared by addition of formalin prior to addition of isotope. The incubations were stopped by the addition of buffered formalin ( $1 \%$ final concentration). Samples were then filtered on to $0.2 \mu \mathrm{m}$ cellulose nitrate filters, washed 10 times with $5 \%$ ice-cold TCA and counted by liquid scintillation counting. The incorporated ${ }^{3} \mathrm{H}$-thymidine was converted to cell production using a factor of $1.1 \times 10^{18}$ cells $\mathrm{mol}^{-1}$ thymidine incorporated (Riemann et al. 1987). To test whether the incubation time was appropriate, we incubated triplicate samples from the same station for 1 and $2 \mathrm{~h}$; the incorporation in each sample was the same

Nanoflagellates. The abundance of autotrophic and heterotrophic nanoflagellates was determined by epifluorescense microscopy on filters stained by proflavine (Haas 1982). Samples were fixed by $1 \%$ glutaraldehyde. The diameters of 100 cells per filter were measured, and biomass was calculated assuming spherical shape and a conversion factor of $0.12 \mathrm{pg} \mathrm{C}$ 
$\mathrm{\mu m}^{-3}$ (Edler 1979). Clearance rates were estimated as $10^{5}$ body volume $\mathrm{h}^{-1}$, converted to in situ temperature by a $Q_{10}$ of 2.5. Growth rates were estimated by assuming $40 \%$ efficiency (Fenchel 1986).

Ciliates and heterotrophic dinoflagellates $>20 \mu \mathrm{m}$. The samples $(200 \mathrm{ml})$ were fixed in $1 \%$ acid Lugol's solution and counted after $24 \mathrm{~h}$ sedimentation using inverted microscopy. Identification of ciliates to species or morphotypes was based on Leegaard (1915), Kahl (1932) and Lynn et al. (1988). The dinoflagellates were identified according to Dodge (1985). Dinoflagellates $<20 \mu \mathrm{m}$ were enumerated on the filters together with the nanoflagellates. Biovolume was estimated from linear dimensions assuming simple geometrical shapes and converted to biomass using con-

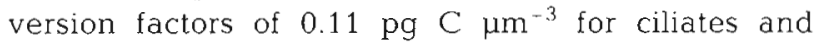
athecate dinoflagellates and $0.13 \mathrm{pg} \mathrm{C} \mathrm{mm}^{-3}$ for thecate dinoflagellates (Edler 1979). Production of protozooplankton was calculated as biomass times maximum growth rates $\left(0.3 \mathrm{~d}^{-1}\right)$. The maximum growth rate applied originates from experiments conducted at 2 to $5^{\circ} \mathrm{C}$ in the Northeast Water Polynya at surplus food with the ciliate Laboea crassula [equivalent spherical diameter (ESD) $45 \mu \mathrm{m}$ ) and the dinoflagellate Gyrodinium spirale (ESD $30 \mu \mathrm{m}$ ) (Nielsen unpubl. data). Ingestion rates were calculated from growth rates assuming complete heterotrophy and $40 \%$ growth efficiency.

Mesozooplankton. Mesozooplankton in the upper $50 \mathrm{~m}$ was sampled by vertical hauls with a WP2 net (200 $\mu \mathrm{m}$ mesh size) equipped with a flow meter (Digital Model 438 110, Hydro Bios) and a large non-filtering cod-end. At the beginning and at the end of the investigation the vertical distribution of mesozooplankton was described by sampling in 3 depth strata ( 0 to $50 \mathrm{~m}, 50$ to $100 \mathrm{~m}$, and 100 to $200 \mathrm{~m}$ ). The samples were preserved in buffered formalin $(2 \%$ final concentration), and at least 300 individuals were analysed. To distinguish between copepodites of Calanus spp., length criteria after Unstad \& Tande (1991) were used. The carbon content of the Calanus spp. females from the egg production experiment was measured. The females were washed in GF/F filtered seawater and dried at $60^{\circ} \mathrm{C}$ for $24 \mathrm{~h}$ before deep freezing. The carbon content was measured with a Perkin Elmer CHN analyser $(240$ C) or with an infrared gas analyser (ADC $225 \mathrm{MK} 3$ ). The ash-free dry weights of other copepod stages and species were obtained from the literature: Calanus spp. copepodites and Metridia longa from Hirche \& Mumm (1992); Pseudocalanus spp. from Robertson (1968); and Oithona spp. from Krylov (1968). The Calanus spp. nauplii weight was assumed to be $33 \%$ of the mass of CI. The carbon content of Calanus spp. stages I to III and the smaller species was assumed to be
$50 \%$ of dry weight, while a conversion factor of $60 \%$ was used for the older stages of Calanus spp. (Omori 1969. Hansen et al. 1994a). Egg carbon was estimated from egg volume by assuming $0.14 \mathrm{pg} \mathrm{C} \mathrm{mm}^{-3}$ (Kiørboe et al. 1985a).

Grazing. When the plankton net arrived on deck, 10 females of Calanus hyperboreus from 0 to $50 \mathrm{~m}$ were immediately added into scintillation vials with $5 \mathrm{ml}$ $96 \%$ ethanol for extraction of gut pigments 110 replicates). The samples were stored deep frozen until analysis according to Huntley et al. (1987). Gut fluorescence was measured on a Turner Design fluorometer, and the gut content (ng chlorophyll equivalents $=$ chl $a$ + phaeophytin a) was calculated according to Wang \& Conover (1986). Gut content was converted to carbon by the actual carbon/chl a ratio of 31 . Instantaneous gut defecation rate constants of $0.015 \mathrm{~min}^{-1}$ (Hansen et al. 1990) were used in the estimates of grazing rates. Body size for all females in each sample was measured, and body carbon and nitrogen were measured on the CHN analyser or the infrared gas analyser. The total community grazing was calculated assuming an equal defecation rate constant for all copepodite stages (Hansen et al. 1990) and a constant weight- specific grazing rate for all species and developmental stages (Berggreen et al. 1988).

Egg production. A sample of gently collected mesozooplankton was diluted in surface water and brought to the laboratory. Production of eggs by female Calanus finmarchicus, $C$. glacialis, and $C$. hyperboreus was measured by incubating 1 to 3 females in $600 \mathrm{ml}$ polycarbonate bottles (at least 6 replicates per species) for 24 to $40 \mathrm{~h}$. The bottles were wrapped in dark nylon mesh and incubations were performed at in situ temperature $\left( \pm 1^{\circ} \mathrm{C}\right)$ in the glacier stream close to the Arctic station. At the end of the experiments the spawned eggs were counted. Production of the copepods was calculated from the weight-specific egg production rate, assuming juvenile somatic growth rates were equal to specific egg production rate (Berggreen et al. 1988). Ingestion was calculated assuming a gross growth effiency of $33 \%$ (Peterson 1988). Egg production versus chl a $>11 \mu \mathrm{m}$ was plotted, and an interactive non-linear regression performed, followed by an analysis of variance. The significance level was found by 2 -tailed distribution of the F-ratio.

\section{RESULTS}

\section{Hydrography and distribution of nutrients}

Disko Bay was covered with ice until mid-May, whereafter coverage was about $50 \%$ During the first 
Table 1. Average $\pm \mathrm{SD}$ of salinity, nutruents and chl a below the photic zone. Number of measurements in parenthesis ( $\mathrm{n}$ )

\begin{tabular}{|c|c|c|c|c|c|c|}
\hline Depth (m) & Salinity $(\%)$ & Phosphate $(\mu M)$ & Nitrate $(\mu M)$ & Nitrite $(\mu \mathrm{M})$ & Silicate $(\mu \mathrm{M})$ & Chl $d\left(\mu \mathrm{g} \mathrm{I}^{-1}\right)$ \\
\hline $50^{4}$ & $33.58 \pm 0.16(6)$ & $0.8 \pm 0.1(7)$ & $8.4 \pm 0.8(7)$ & $0.19 \pm 0.04(7)$ & $7.1 \pm 0.7(5)$ & $1.0 \pm 0.3(5)$ \\
\hline 100 & $33.83 \pm 0.10(4)$ & $0.8 \pm 0.3(5)$ & $10.1 \pm 0.5(5)$ & $0.14 \pm 0.01(5)$ & $7.6 \pm 0.8(5)$ & $1.0 \pm 0.5\{5\}$ \\
\hline 200 & $3428 \pm 0.05(4)$ & $1.2 \pm 0.03(7)$ & $13.3 \pm 0.3(7)$ & $0.10 \pm 0.01(7)$ & $15.2 \pm 0.6(7)$ & $0.2 \pm 0.1(3)$ \\
\hline
\end{tabular}

3 weeks of June the ice coverage varied between 1 and $60 \%$, averaging $20 \%$ (N. Nielsen pers. comm.). Normally the sea ice leaves Disko Bay off Godhavn in April-May (Andersen 1981b). However, on arrival on 20 June, the Bay was $60 \%$ covered with sea ice. This investigation was initiated $3 \mathrm{~d}$ after the sea ice melted. The weather was dominated by a high pressure system, with high solar radiation, clear skies and low wind. This greatly influenced the structure of the water column resulting in the development of strong salinity and temperature gradients (Fig. 2A, B). The vertical distribution of salinity was influenced by melting sea ice, glaciers and runoff from land, resulting in a less saline surface layer ( 31.2 to $32 \%$ ). The increasing thickness of the less saline surface layer is illustrated by the depth of the $33 \%$ isoline, which decreased from about $10 \mathrm{~m}$ in the beginning to about $20 \mathrm{~m}$ on the last sampling day. The salinity at the bottom of the photic zone $(30 \mathrm{~m})$ varied between 33.3 and $33.6 \%$, increasing to $33.6,33.8$ and $34.3 \%$ at 50,100 and $200 \mathrm{~m}$ depth. respectively (Table 1 ).

On the first day of sampling the upper $20 \mathrm{~m}$ of the water column was almost thermally uniform at approximately $0^{\circ} \mathrm{C}$ (Fig. $2 \mathrm{~B}$ ). Thereafter, the surface temperature increased about $0.5^{\circ} \mathrm{C} \mathrm{d}^{-1}$ until a peak of $3.8^{\circ} \mathrm{C}$ on 28 June, whereupon the temperature varied between 2.2 and $5.9^{\circ} \mathrm{C}$ depending on daily solar radiation. The depth of the warm surface layer roughly parallels the distribution of lower salinity waters in the upper layer, where positive temperatures only were recorded above the $33 \%$ isoline. The temperature below the photic zone varied between -0.3 and $-0.7^{\circ} \mathrm{C}$.

The nutrient concentrations in the warm, less saline surface water were low, $0.11 \pm 0.06,0.06 \pm 0.04$ and $0.7 \pm 0.6 \mu \mathrm{M}(\mathrm{n}=42)$ for phosphate, nitrate and silicate, respectively. During the deepening of the surface layer, nutrients were depleted (Fig. $2 \mathrm{C}$ to $\mathrm{E}$ ), and the concentration of nitrate decreased to below detection level. The vertical distribution of nitrite followed the same trend (data not shown) but with a concentration less than $10 \%$ of the nitrate concentration (Table 1 ). The nutricline was located deeper than the pycnocline, in association with the $33.4 \%$ isoline. High concentrations of nutrients were measured below the photic zone increasing towards the bottom (Table 1).

\section{Phytoplankton composition, biomass and production}

The temporal and vertical distribution of fluorescence was dominated by a sedimenting phytoplankton bloom. After the first sampling, high values of fluorescence were only recorded below the $33 \%$ isoline associated with the nutricline (Fig. $3 \mathrm{~A}$ ). As the bloom sank the secchi depth gradually increased from $6 \mathrm{~m}$ in the first 2 samplings to $12 \mathrm{~m}$ on the last visit to the station (data not shown). In the following 'photic zone' refers to the upper $30 \mathrm{~m}$ of the water column where net primary production was measured.

Species composition and biovolume of the phytoplankton in the sample containing the highest fluorescence revealed that large diatoms [Coscinodiscus spp. (10 to $60 \mu \mathrm{m})$, Thalassiosira fallax (20 to $45 \mu \mathrm{m}), T$. gravida (15 to $30 \mu \mathrm{m})$ and Fragilaria islandica $(15 \mu \mathrm{m})$ ] generally dominated the phytoplankton biomass. The mean carbon/chl a (wt/wt) ratio for the whole period, including the contribution from the nanoflagellates, was $31 \pm 17, \mathrm{n}=10$. The autotrophic nanoflagellates contributed less than $5 \%(4.1 \pm 2.2 \%, \mathrm{n}=10)$ to the phytoplankton carbon. The size fractionated chl a samples, where the fraction $>11 \mu \mathrm{m}$ contributed 60 to $100 \%(90 \pm 13 \%)$ of the total chlorophyll (Fig. 4A), provided further evidence for the dominance of large cells. This finding is supported by microscopic examination of samples from the fluorescence peak (Fig. $4 \mathrm{~B}$ ). The relative size distribution was constant in the peak samples throughout the investigation while the importance of the smaller diatoms (10 to $20 \mu \mathrm{m})$ increased at the peak as the bloom became nutrient depleted.

The vertical distribution of primary production followed the trends in the distribution of the phytoplankton biomass. On the first sampling date the production was 40 to $90 \mu \mathrm{g} \mathrm{Cl}^{-1} \mathrm{~d}^{-1}$ throughout the photic zone. Thereafter the highest production $\left(10\right.$ to $30 \mu \mathrm{g} \mathrm{C} \mathrm{l}^{-1}$ 


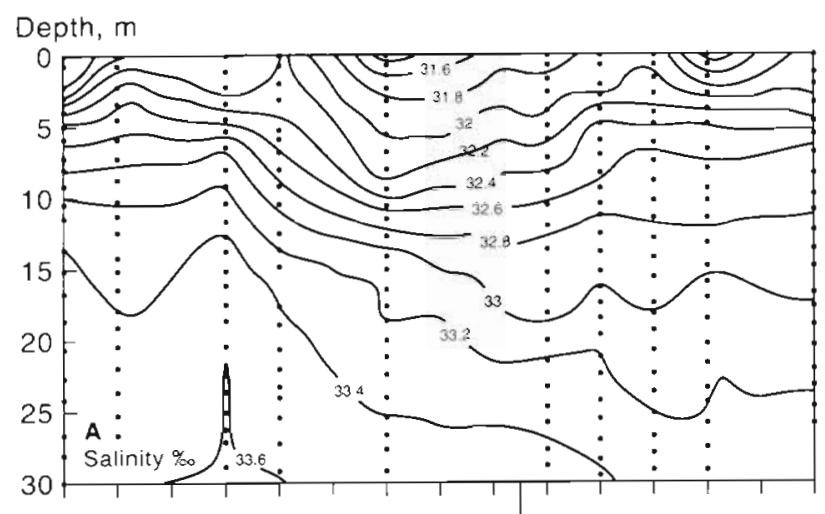

Depth, $m$
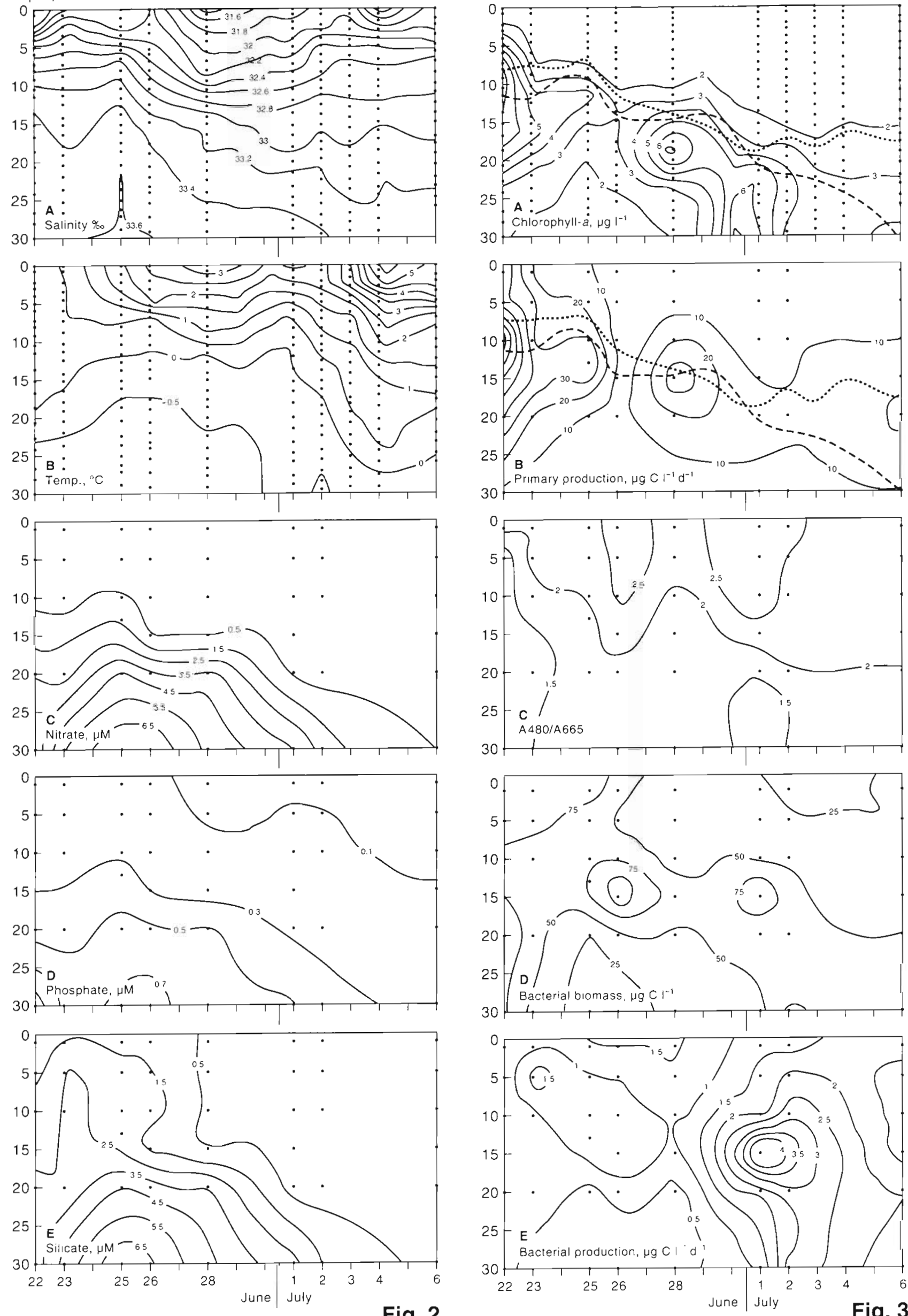

Fig. 2

Fig. 3 
Table 2. Bacterial biomass (BB) and bacterial production (BP) expressed as percent of phytoplankton biomass (PB) and primary production (PP), during and after the sedimentation of a diatom bloom

\begin{tabular}{|c|c|c|c|c|c|c|c|c|}
\hline & \multicolumn{5}{|c|}{ June } & \multicolumn{3}{|c|}{ July } \\
\hline & 22 & 23 & 25 & 26 & 28 & 1 & 2 & 6 \\
\hline $\mathrm{BB} / \mathrm{PB}$ & 67 & 71 & 71 & 92 & 45 & 53 & 58 & 58 \\
\hline $\mathrm{BP} / \mathrm{PP}$ & 1 & 5 & 5 & $17^{a}$ & 2 & 31 & 30 & 11 \\
\hline
\end{tabular}

$\mathrm{d}^{-1}$ ) was measured in the subsurface layer associated with the sedimenting bloom (Fig. 3B).

\section{Bacterioplankton biomass and production}

The bacterial biomass varied between 25 and $100 \mu \mathrm{g} \mathrm{C}$ $\mathrm{l}^{-1}$, corresponding to 0.6 to $3.1 \times 10^{6}$ cells $\mathrm{ml}^{-1}$. The average bacterial cell size was $0.108 \pm 0.044 \mu^{3}$ ( $n=2250$ ). The vertical distribution of bacteria followed the phytoplankton biomass and production, with the highest biomass located in the middle of the water column (Fig. 3D).

Bacterial production rates showed the same vertical distribution as the bacterial biomass, with the highest production in the middle of the water column (Fig. 3E). After the diatom bloom sank out of the photic zone the bacterial production increased from

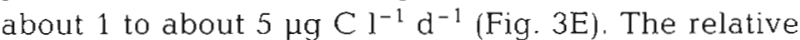
importance of the bacterioplankton production expressed by the ratio between bacterial and primary production also increased after the bloom left the photic zone (Table 2).

\section{Heterotrophic nanoflagellates}

This group contains bacterivorous nanoflagellates and heterotrophic dinoflagellates $<20 \mu \mathrm{m}$. The bacterivorous nanoflagellates were most abundant (100 to 1100 cells $\mathrm{ml}^{-1}$ ). Heterotrophic dinoflagellates were less abundant with 100 to 400 cells $\mathrm{ml}^{-1}$. Mean cell volumes for the nanoflagellates and heterotrophic dinoflagellates $<20 \mu \mathrm{m}$ were 98 and $642 \mu \mathrm{m}^{3}$, respectively. So, due to their larger cell size, the dinoflagellates

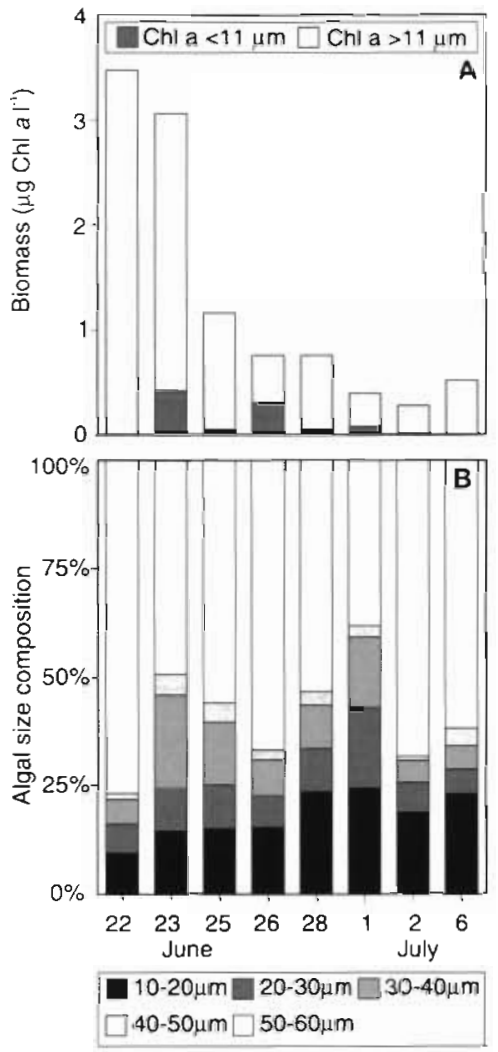

Fig. 4. Size distribution of the phytoplankton: (A) fractionated chl $a$ in the upper $1 \mathrm{~m}$ of the surface layer and (B) size distribution of phytoplankton sampled at the depth of maximum concentration

dominated the biomass within the smallest fractions of grazers. The vertical distribution of the nanoflagellates was relatively patchy with the highest biomass found in the surface water (Fig. 5A, B).

\section{Ciliates and heterotrophic dinoflagellates $>20 \mu \mathrm{m}$}

Ciliates dominated the microzooplankton, although heterotrophic dinoflagellates $>20 \mu \mathrm{m}$ contributed significantly to the microzooplankton biomass after the diatom bloom left the photic zone (Table 3).

The 35 identified species or morphotypes of ciliates were dominated by aloricate oligotrichs (dominated by Lohmaniella oviformis 10 to $20 \mu \mathrm{m}$ and Strombidium and Strobilidium spp. 40 to $60 \mu \mathrm{m}$ ), with tintinnids

Fig. 2. Vertical distribution of (A) salinity, (B) temperature, (C) nitrate, (D) phosphate, and (E) silicate, at the Disko Bay station during the study period. Dots indicate sampling depths

Fig. 3. Vertical distribution of (A) phytoplankton biomass, (B) primary production, (C) the absorption ratio $A_{480} / A_{665}$, (D) bacterial biomass and (E) bacterial production. Depth of the $33 \%$ isoline ( ........) and nutricline (-.--) $(0.5 \mu \mathrm{M}$ nitrate) indicated in (A) and

(B). Dots indicate sampling depths 
Depth, $m$
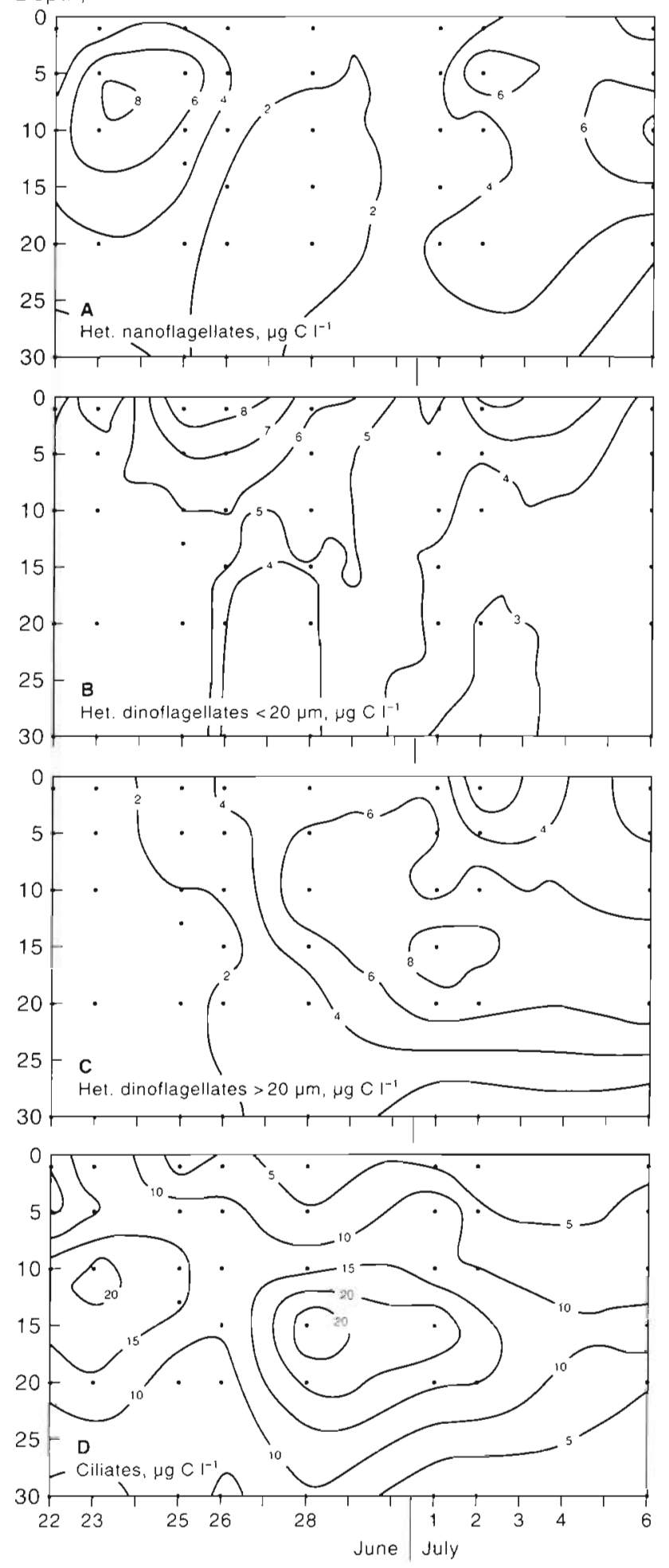

Fig. 5. Vertical distribution of biomasses of (A) heterotrophic nanoflagellates, (B) heterotrophic dinoflagellates $<20 \mu \mathrm{m}$, (C) heterotrophic dinoflagellates $>20 \mu \mathrm{m}$ and (D) ciliates. Dots indicate sampling depths (predominantly Psycocylis sp., Tintinnopsis denticulata and $T$. parvula) and 'others' (dominated by Didinium sp. and Uronema sp.) being minor components. Abundance of these 3 groups ranged from 1000 to 22500 ,

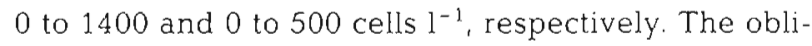
gate autotroph Mesodinium rubrum was only found in

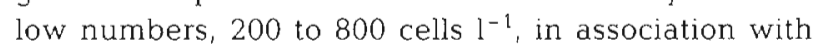
the nutricline. The highest ciliate biomass of 20 to 25 $\mu \mathrm{g} \mathrm{C} 1^{-1}$ was located in the middle of the water column associated with the diatom bloom. (Fig. 5D).

The heterotrophic dinoflagellates $>20 \mu \mathrm{m}$ were dominated by naked forms (Gyrodinium glaucum and $G$. spirale). The only thecate species was the small Protoperidinium bipes. The abundance of the 2 groups ranged between 400 and 11000 and between 500 and 1400 cells $1^{-1}$, respectively. $G$. spirale (50 to $100 \mu \mathrm{m}$ ) dominated the biomass, which reached a maximum $\left(8 \mu \mathrm{g} \mathrm{C}^{-1}\right)$ in the middle of the water column after the bloom left the photic zone (Fig. 5C).

\section{Copepod composition, biomass and vertical distribution}

Copepods dominated the mesozooplankton. Calanus spp. formed most of the biomass (Figs. $6 \& 7$ ). $C$. glacialis and $C$. hyperboreus constituted more than $80 \%$ of the Calanus spp. biomass; the rest was C. finmarchicus. Pseudocalanus acuspes, P. minutus, and Acartia longiremis were rare in the upper $50 \mathrm{~m}$. Metridia longa was present in low abundance in the deep water (Fig. 7). The cyclopoid Oithona spp., as well as unidentified nauplii, was present, though not sampled representatively.

The copepod biomass in the upper $50 \mathrm{~m}$ of the water column varied between 20 and $90 \mathrm{mg} \mathrm{C} \mathrm{m}^{-3}$ (Fig. 6). The vertical distribution of the copepods was investigated twice (Fig. 7): 84 and $49 \%$ of the biomass $\mathrm{m}^{-2}$ was found in the upper $50 \mathrm{~m}$ on 25 June (Fig. 7 A) and 2 July (Fig. 7B), respectively. On 25 June, the biomass in the 50 to $100 \mathrm{~m}$ stratum was low, and the biomass in the bottom water was negligible. On 2 July more copepods were located in the 50 to $100 \mathrm{~m}$ stratum. The less distinct accumulation of copepods in the surface at the last sampling occasion could be due to a feeding migration by copepods following the sedimentation of the bloom to this stratum (Table 1).

\section{Stage composition and vertical distribution of the Calanus spp.}

The stage composition was analysed for the Calanus spp, populations (Fig. 8). An increasing relative abundance of juvenile stages $(\mathrm{Cl}, \mathrm{CII})$ for $\mathrm{C}$. fin- 
Table 3. Average biomass of phytoplankton and ANAN (autotrophic nanoflagellates), bacteria and protozoa (HNAN: heterotrophic nanoflagellates; $\mathrm{H}$-din: heterotrophic dinoflagellates), and primary and bacterial production in the photic zone during and after the sedimentation of a diatom bloom

\begin{tabular}{|c|c|c|c|c|c|c|c|c|c|}
\hline \multirow[t]{2}{*}{ Date } & \multicolumn{7}{|c|}{ Biomass ( $\mathrm{mg} \mathrm{C} \mathrm{m} \mathrm{m}^{-3}$ ) } & \multicolumn{2}{|c|}{ Production ( $\mathrm{mg} \mathrm{C} \mathrm{m}^{-3} \mathrm{~d}^{-1}$ ) } \\
\hline & Phytoplankton & ANAN & Bacteria & HNAN & $H-\operatorname{din}<20 \mu \mathrm{m}$ & $\mathrm{H}$-din $>20 \mu \mathrm{m}$ & Ciliates & Phytoplankton & Bacterna \\
\hline Jun 22 & 142 & 7.0 & 95 & 3.1 & 8.7 & 1.6 & 10.8 & 48.1 & 0.7 \\
\hline 23 & 89 & 7.0 & 64 & 5.0 & 9.4 & 1.3 & 15.3 & 21.1 & 1.0 \\
\hline 25 & 69 & 2.7 & 49 & 4.2 & 8.7 & 1.6 & 10.9 & 14.4 & 0.7 \\
\hline 26 & 60 & 1.5 & 55 & 1.9 & 8.6 & 3.1 & 10.6 & 4.5 & 0.8 \\
\hline 28 & 95 & 3.2 & 43 & 1.6 & 7.7 & 5.5 & 20.7 & 27.2 & 0.6 \\
\hline Mean $\pm \mathrm{SD}$ & $91 \pm 29$ & $4.3 \pm 2.6$ & $61 \pm 18$ & $3.2 \pm 1.5$ & $8.6 \pm 0.6$ & $2.6 \pm 1.8$ & $13.7 \pm 4.4$ & $23 \pm 15$ & $0.8 \pm 0.1$ \\
\hline Jul 1 & 100 & 3.6 & 53 & 3.0 & 9.5 & 6.9 & 16.4 & 7 & 2.2 \\
\hline 2 & 80 & 3.6 & 46 & 4.8 & 6.3 & 4.7 & 9.4 & 8.7 & 2.6 \\
\hline 3 & 62 & & & & & & & & \\
\hline 4 & 67 & & & & & & & & \\
\hline 6 & 67 & 5.2 & 39 & 4.5 & 5.3 & 6.8 & 7.1 & 13.9 & 1.4 \\
\hline Mean $\pm \mathrm{SD}$ & $75 \pm 14$ & $4.1 \pm 0.9$ & $46 \pm 6$ & $4.1 \pm 1.0$ & $7.0 \pm 2.2$ & $6.1 \pm 1.2$ & $11.0 \pm 4.8$ & $10 \pm 1$ & $2.0 \pm 0.50$ \\
\hline
\end{tabular}

marchicus and C. glacialis was observed during the investigation. The abundance of $C$. finmarchicus females was significantly higher than $\mathrm{CV}$, in contrast to $C$. glacialis where $\mathrm{CV}$ was the most abundant stage present. C. hyperboreus showed a more constant stage composition, dominated by copepodites older than CIII, and particularly CV.

At the start of the investigation the Calanus spp. in the 3 depth strata were dominated by advanced copepodite stages (adults and CV) (Fig. 9A). By the end of the period, however, in addition to a high frequency of $\mathrm{CV}$ and adults of Calanus spp., C. finmarchicus $\mathrm{CI}$ and CII were numerous in the upper $100 \mathrm{~m}$ (Fig. 9B). In general both CII and CIII of C.

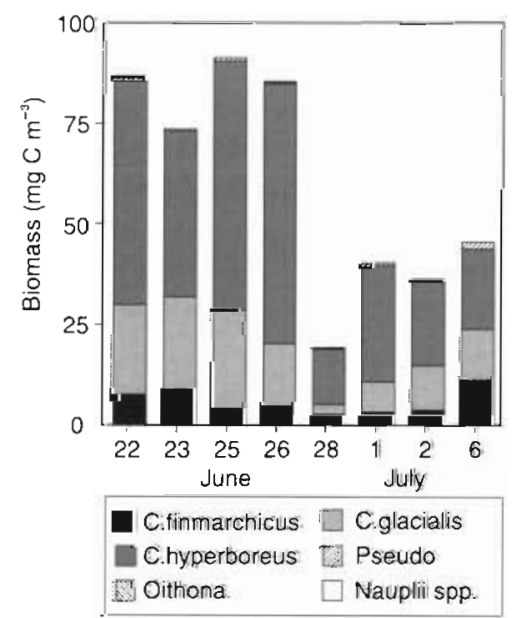

Fig. 6. Average copepod biomass in the upper $50 \mathrm{~m}$ of the water column. C: Calanus; Oithona: Oxthona spp.; Pseudo: Pseudocalanus spp glacialis and $C$. hyperboreus were of increasing importance in the 0 to $100 \mathrm{~m}$ water mass, indicating a response to the bloom. The abundance of advanced copepodite stages of all 3 species was modest in the bottom water on 2 July.

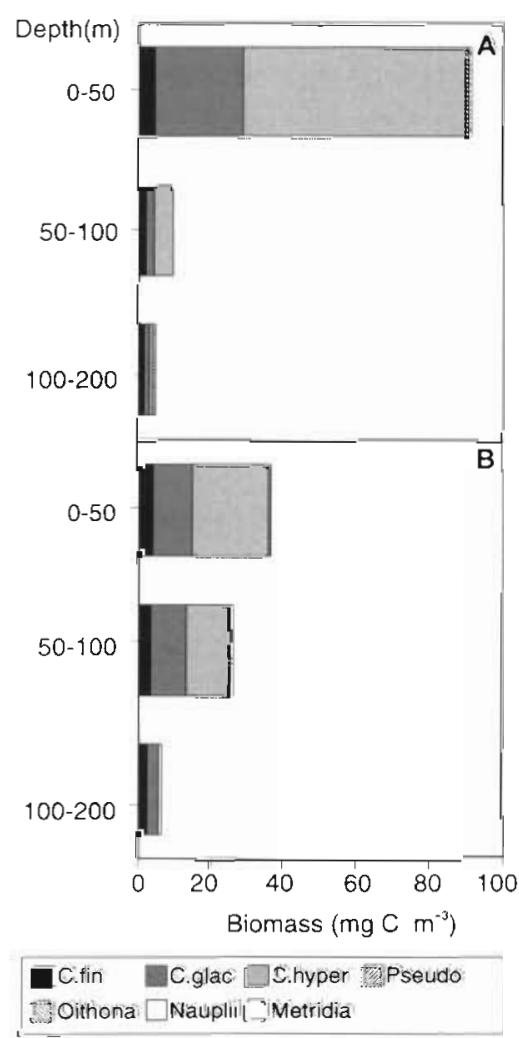

Fig. 7 Vertical distribution of copepod biomass on (A) 25 June and (B) 2 July. Species names as in Fig. 6, plus Metridia: Metridia longa 


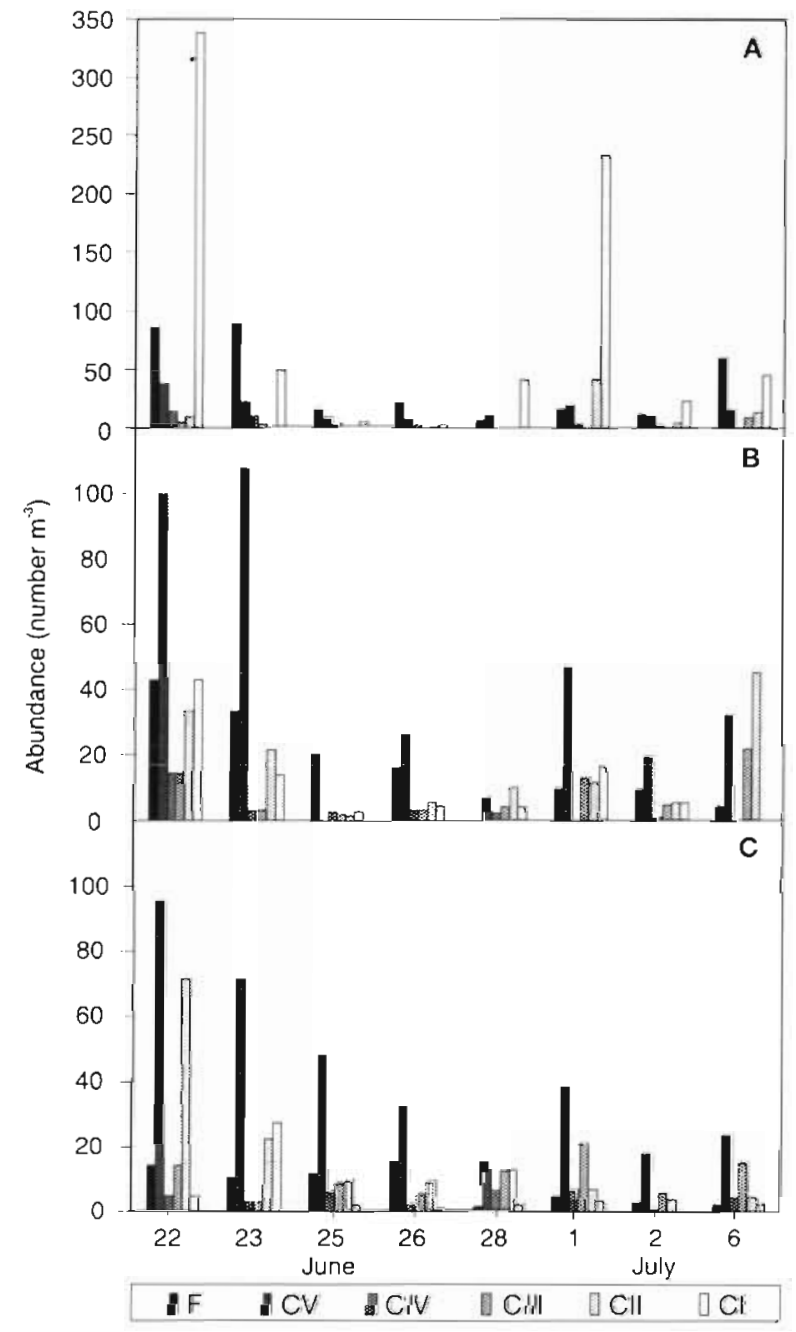

Fig. 8. Calanus spp. Development of stage composition in the upper $50 \mathrm{~m}$ of the water column. (A) C. finmarchicus, (B) C. glacialis and (C) C. hyperboreus
Egg production of Calanus spp.

Only females of the 3 Calanus species were so abundant that egg production experiments could be conducted throughout the investigation. All Calanus species produced eggs (Table 4). The smaller Calanus species had the highest fecundity: $C$. finmarchicus and $C$. glacialis produced an average $( \pm \mathrm{SD})$ of $16.6 \pm$ 13.5 (range 1 to 74 ) and $17.7 \pm 13$ (range 0 to 67 ) eggs $\mathrm{Q}^{-1} \mathrm{~d}^{-1}$, respectively. The egg production rate of the larger $C$. hyperboreus was generally much lower: $1.4 \pm 1.7$ (range 0 to 8.8 ) eggs $q^{-1} \mathrm{~d}^{-1}$. The egg production rate of $C$. finmarchicus and $C$. glacialis correlated weakly but positively with the concentration of chl $a>11 \mu \mathrm{m}$ in the surface water $\left(\mathrm{r}^{2}=0.31, \mathrm{n}=15\right.$, $p<0.05$; Fig. 10). C. hyperboreus egg production rate did not correlate with the ambient chl a concentration.

\section{Grazing by the copepod community}

The grazing impact of the copepod community was estimated by 3 approaches. These attempts only include the Calanus spp., which represent $95 \%$ of the total copepod biomass. C. hyperboreus alone makes up approximately $65 \%$ of the copepod biomass. The gut content of $C$. hyperboreus females ranged from 0.519 to $1.007 \mu \mathrm{g}$ chlorophyll equivalents ${ }^{-1}$, equivalent to a daily ration of 10 to $19 \%$ (Table 5). If a constant weight-specific grazing rate is assumed for the whole copepod community, a carbon demand of 3 to $11 \mathrm{mg} \mathrm{C} \mathrm{m} \mathrm{m}^{-1}$ can be calculated from the daily ration of $C$. hyperboreus. This amounts to $11-188 \%$ (mean $80 \pm 55 \%$ ) of the average primary production $\mathrm{m}^{-3} \mathrm{~d}^{-1}$

Table 4. Calanus spp. Summary of the egg production rate (eggs $q^{-1} \mathrm{~d}^{-1}$ mean $\pm \mathrm{SD}$, maximum and minimum values, with numbers of experiments in parentheses) of the dominating copepods during and after the sedimentation of a diatom bloom

\begin{tabular}{|c|c|c|c|c|c|c|c|c|}
\hline Calanus spp. & Jun 22 & Jun 23 & Jun 25 & Jun 26 & Jun 28 & Jul 1 & Jul 2 & Jul 6 \\
\hline \multicolumn{9}{|l|}{ C. finmarchicus } \\
\hline Mean $\pm S D$ & $21.5 \pm 8.6$ & $19.2 \pm 11.2$ & $23.6 \pm 7.3$ & $8.2 \pm 6.9$ & $4.9 \pm 4.3$ & $25.4 \pm 21.6$ & $16.1 \pm 5.0$ & $18.7 \pm 13.8$ \\
\hline $\operatorname{Max}, \min (n)$ & $38,13(6)$ & $41,9(6)$ & $31,12(6)$ & $18,1(6)$ & $13,1(6)$ & $74,3(8)$ & $25,11(5)$ & $41,3(6)$ \\
\hline \multicolumn{9}{|l|}{ C. glacialis } \\
\hline Mean \pm SD & 36 & 32 & $28 \pm 8.0$ & $8.6 \pm 8.9$ & $11 \pm 11$ & $20 \pm 18$ & $14.8 \pm 7.4$ & $13 \pm 7$ \\
\hline $\operatorname{Max}, \min (n)$ & $36(1)$ & $32(1)$ & $43,19(6)$ & $28,2(6)$ & $33,1(6)$ & $68,4(8)$ & $23,5(8)$ & $26,5(6)$ \\
\hline \multicolumn{9}{|l|}{ C. hyperboreus } \\
\hline Mean $\pm S D$ & $2.3 \pm 1.3$ & $1.4 \pm 0.8$ & $0.4 \pm 0.4$ & $0.9 \pm 0.2$ & $1.1 \pm 1.8$ & $3.6 \pm 2.7$ & $0.7 \pm 0.3$ & $0.2 \pm 0.4$ \\
\hline $\operatorname{Max}, \min (\mathrm{n})$ & $5,1(9)$ & $4,1(10)$ & $1,0(6)$ & $2,0(6)$ & $5,0(5)$ & $9,0(8)$ & $1,0(8)$ & $1,0(6)$ \\
\hline
\end{tabular}


If the carbon demand of the copepod community is estimated from the actual specific egg production rate, ingestion rates are much lower: 0.4 to $4.6 \mathrm{mg} \mathrm{C} \mathrm{m}^{-3} \mathrm{~d}^{-1}$. These values amount to $1-22 \%$ (mean $15 \pm 6 \%$ ) of the average primary production $\mathrm{m}^{-3}$ $\mathrm{d}^{-1}$. This difference is mainly due to the low egg production by the dominating Calanus hyperboreus, which presumably spawn before the spring bloom, relying on lipid reserves from the previous year. However, the $C$. hyperboreus in the upper $50 \mathrm{~m}$ were actively feeding and thus contributed significantly to the grazing of the phytoplankton (Table 5). If we calculate the grazing impact, assuming that the average specific egg production rate of $C$. glacialis and C. finmarchicus represents the somatic growth rate, and thereby the grazing rate of the entire copepod community, a more realistic grazing rate is achieved 10.7 to $11.9 \mathrm{mg} \mathrm{C} \mathrm{m} \mathrm{m}^{-3}$ ). This would result in a grazing impact of about half of the value achieved by the estimates from the gut florescence method: 25 to $81 \%$ of the average primary production $\mathrm{m}^{-3}$ $\mathrm{d}^{-1}$ (mean $44 \pm 28 \%$ ) (Table 6). For providing carbon specific results, female characteristics are given in Table 7 . The high variability in the above estimates of the grazing pressure by the copepod community is mainly due to the variation in the biomass of copepods in the upper $50 \mathrm{~m}$ of the water column.
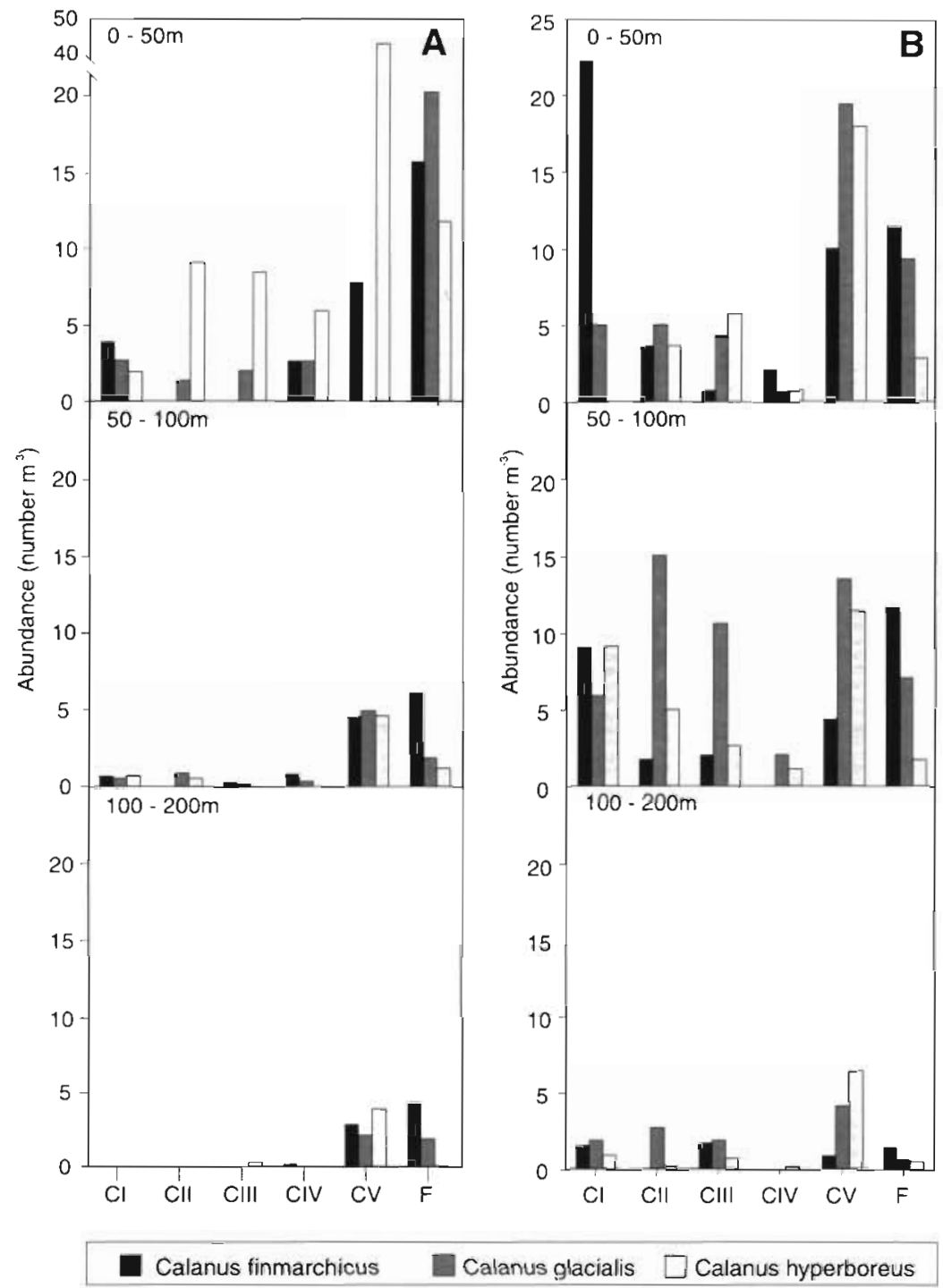

Fig. 9. Calanus finmarchicus, C. glacialis and C. hyperboreus. Vertical distribution of developmental stages on (A) June 25 and (B) July 2

\section{DISCUSSION}

\section{Hydrography and regulation of the primary production}

Disko Bay was greatly influenced by melting ice. This caused a pronounced vertical and horizontal salinity gradient as surface water passed Godhavn on its way out of the Bay. The late ice cover in 1992 delayed the stratification of the Bay. Thermal stratification with positive temperatures in the surface is normally established by mid-May (Andersen 1981a). However, during this study positive surface temperatures were first recorded on the second visit to the sampling position on 23 June (Fig. 2B); thereafter the stable weather with
Table 5. Calanus hyperboreus. Gut content (mean \pm SD), grazing and daily ration (carbon intake as percentage of body carbon) of C. hyperboreus sampled in the upper $50 \mathrm{~m}$. Calculations based on a female carbon content of $3.620 \mu \mathrm{g} \mathrm{C}$ and a chl a:carbon ratio of 31

\begin{tabular}{|cccc|}
\hline Date & $\begin{array}{c}\text { Gut content } \\
\left(\mu \mathrm{g} \text { chl equiv. } \rho^{-1}\right)\end{array}$ & $\begin{array}{c}\text { Grazing } \\
\left(\mu \mathrm{C}^{-1} \mathrm{~d}^{-1}\right)\end{array}$ & $\begin{array}{c}\text { Daily ration } \\
(\%)\end{array}$ \\
\hline Jun 25 & $0.637 \pm 0.140$ & 427 & 12 \\
26 & $0.519 \pm 0.044$ & 348 & 10 \\
28 & $0.807 \pm 0.158$ & 540 & 15 \\
Jul 1 & $0.876 \pm 0.111$ & 587 & 16 \\
2 & $0.641 \pm 0.069$ & 429 & 12 \\
6 & $1.007 \pm 0.195$ & 674 & 19 \\
\hline
\end{tabular}


Table 6. Total copepod biomass and community grazing estimated by 3 methods: (1) the gut fluorescence of Calanus hyperboreus assuming a constant weight specific grazing rate; and (2) the specific egg production rate by all 3 Calanus spp.; and by (3) the average of the specific egg production rate by $C$. finmarchicus and $C$. glacialis, during and after sedimentation of the bloom

\begin{tabular}{|c|c|c|c|c|c|c|c|}
\hline \multirow{3}{*}{ Date } & \multirow{3}{*}{$\begin{array}{l}\text { Copepod } \\
\text { biomass } \\
\left(\mathrm{mg} \mathrm{C} \mathrm{m}^{-3}\right)\end{array}$} & \multirow{3}{*}{\multicolumn{2}{|c|}{$\begin{array}{l}\text { Gut fluorescence method } \\
m g \mathrm{Cm}^{-3} \mathrm{~d}^{-1} \% \text { of PP }\end{array}$}} & \multirow{2}{*}{\multicolumn{2}{|c|}{$\begin{array}{l}\text { Copepod community grazing } \\
\text { Actual egg production rate }\end{array}$}} & \multirow{2}{*}{\multicolumn{2}{|c|}{ Average egg production rate }} \\
\hline & & & & & & & \\
\hline & & & & $m g C m^{-3} d^{-1}$ & $\%$ of PP & $\mathrm{mgC} \mathrm{m}^{-3} \mathrm{~d}^{-1}$ & $\%$ of $\mathrm{PP}$ \\
\hline Jun 22 & 87 & & & 4.6 & 9.6 & 11.9 & 25 \\
\hline 23 & 74 & & & 4.0 & 18.9 & 8.9 & 42 \\
\hline 25 & 92 & 11.5 & 76 & 3.2 & 22.2 & 11.6 & 81 \\
\hline 26 & 85 & 8.5 & 188 & 0.7 & 16.4 & 3.3 & 73 \\
\hline 28 & 20 & 3.0 & 11 & 0.4 & 1.5 & 0.7 & 33 \\
\hline Mean \pm SD & $72 \pm 30$ & $7.5 \pm 4.1$ & $92 \pm 90$ & $2.4 \pm 2.2$ & $13.7 \pm 8.2$ & $7 \pm 5$ & $45 \pm 33$ \\
\hline Jul 1 & 41. & 6.6 & 94 & 1.1 & 15.7 & 4.9 & 70 \\
\hline 2 & 36 & 4.3 & 49 & 1.4 & 16.1 & 2.8 & 32 \\
\hline 6 & 45 & 6.6 & 62 & 2.2 & 158 & 3.9 & 28 \\
\hline Mean $\pm S D$ & $41 \pm 5$ & $6.5 \pm 2.2$ & $80 \pm 60$ & $1.7 \pm 0.6$ & $15.9 \pm 0.2$ & $3.9 \pm 1.1$ & $43 \pm 23$ \\
\hline
\end{tabular}

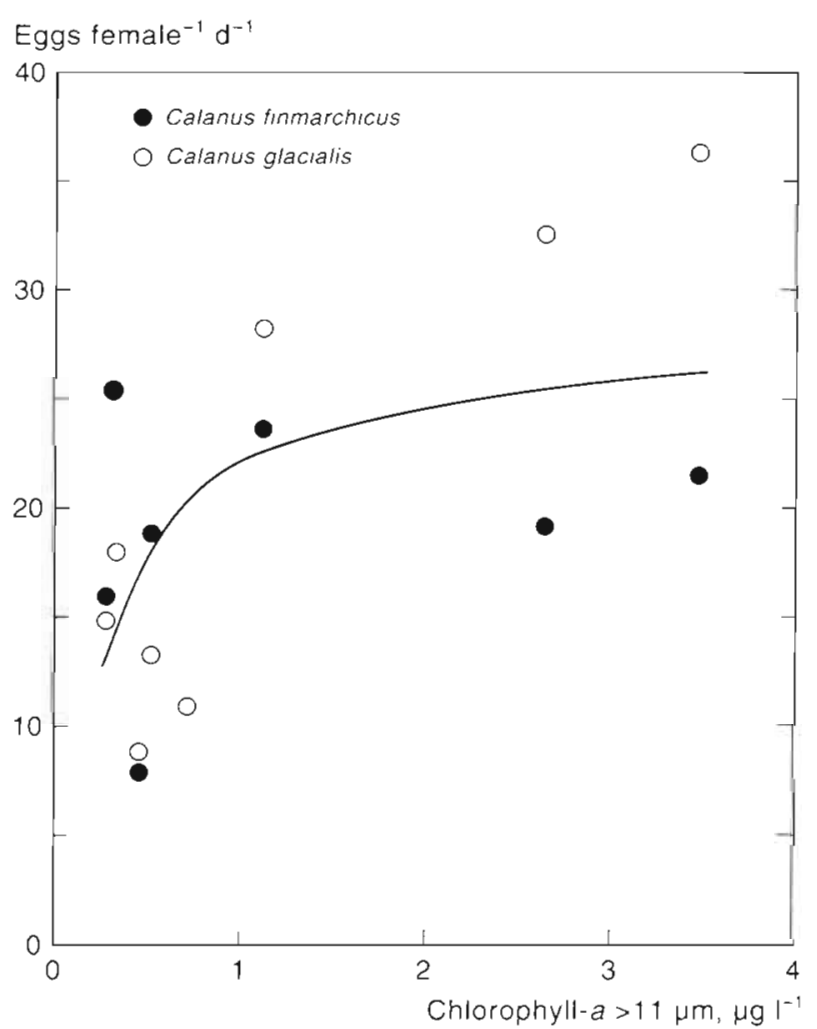

Fig. 10. Calanus finmarchicus and C. glacialis. Monod fit of egg production rate (eggs $Q^{-1} \mathrm{~d}^{-1}$ ) in relation to chl $a>11 \mu \mathrm{m}$ in the surface water: $E=27.8 \mathrm{e}^{-0.22 / \mathrm{chl}}, \mathrm{r}^{2}=0.31, \mathrm{n}=15, \mathrm{p}<$ 0.05 . where $E$ is the egg production and chl is the chl $a>11 \mu \mathrm{m}$ in the surface water

clear skies rapidly heated the surface water and facilitated the development of a strong thermocline (Fig. 2A, B).
Table 7. Female Calanus spp. characteristics. Regression between cephalothorax length $(L, \mathrm{~mm})$ and body weight ( $W$, mg C) for C. finmarchicus and C. glacialis: $W=0.0041 L^{37 i}$, $r^{2}=0.79, n=46$, no measurements

\begin{tabular}{|lrrrr|}
\hline Calanus spp. & $\begin{array}{c}\text { Mean length } \\
(\mathrm{mm})\end{array}$ & $\begin{array}{c}\text { Carbon } \\
\left(\mathrm{mg} \mathrm{g}^{-1}\right)\end{array}$ & C:drywt & $\mathrm{C}: \mathrm{N}$ \\
\hline $\begin{array}{l}\text { C. finmarchicus } \\
(\mathrm{n}=23)\end{array}$ & $2.56 \pm 0.15$ & $0.16 \pm 0.05$ & $\cdot$ & $\cdot$ \\
$\begin{array}{l}\text { C. glacialis } \\
(\mathrm{n}=23)\end{array}$ & $3.44 \pm 0.25$ & $0.49 \pm 0.17$ & $0.51 \pm 0.05$ & 6.5 \\
$\begin{array}{l}\text { C. hyperboreus } \\
(\mathrm{n}=24)\end{array}$ & $6.68 \pm 0.38$ & $3.62 \pm 0.84$ & $0.56 \pm 0.04$ & 9.8 \\
\hline
\end{tabular}

Depending on the character of the ice and snow cover, the spring bloom in Disko Bay off Godhavn is initiated in April-May and sediments out of the photic zone after about 2 wk (Andersen 1981b). On the first sampling date the thermocline was weak, but the nutrient concentration was low. High chl $a$ and primary production (Fig. 3A, B) was recorded throughout the photic zone. This indicates that the bloom was initiated under the ice as observed by Petersen (1964) and Andersen (1981a) in years with late ice breakup.

The productive period off Godhavn normally lasts from the beginning of April to November (Petersen 1964, Andersen 1981a). The spring bloom develops between mid-April and mid-June and lasts for $2 \mathrm{wk}$. Associated with temporal mixing of the surface water and intrusion of nutrients to the surface water, several minor blooms can develop later in the year. However, the stable weather conditions and the strong stratification during our investigation. effectively sealed the nutrients in the deep water. 
During the first part of the bloom the daily primary production was $690 \pm 450 \mathrm{mg} \mathrm{C} \mathrm{m} \mathrm{m}^{-2} \mathrm{~d}^{-1}$. within the range of the 3 previous investigations in the area: 200 to $350 \mathrm{mg} \mathrm{C} \mathrm{m} \mathrm{m}^{-1} \mathrm{~d}^{-1}$ (Steemann Nielsen 1958), 300 to $600 \mathrm{mg} \mathrm{C} \mathrm{m}^{-2} \mathrm{~d}^{-1}$ (Petersen 1964) and 500 to $1500 \mathrm{mg} \mathrm{C}$ $\mathrm{m}^{-2} \mathrm{~d}^{-1}$ (Andersen 1981a). Thereafter the primary production declined to $300 \pm 30 \mathrm{mg} \mathrm{C} \mathrm{m}{ }^{-2} \mathrm{~d}^{-1}$ as the bloom became nutrient depleted and left the photic zone.

The size distribution of the primary producers in Disko Bay was investigated by Andersen (1981b) throughout the productive season: during the spring bloom, phytoplankters $>56 \mu \mathrm{m}$ dominated the biomass and contributed more than $90 \%$ of the primary production. The nutrient depleted period after the bloom was characterized by dominance of smaller cells $(<56 \mu \mathrm{m})$. The late summer blooms caused by the mixing events were again dominated by the larger phytoplankton fraction. Unfortunately, the species composition of the phytoplankton was not investigated by Andersen. During the present investigation diatoms (10 to $60 \mu \mathrm{m}$ ) dominated the phytoplankton biomass both in the surface samples and in the subsurface bloom (Fig. 4). Autotrophic nanoflagellates contributed less than $10 \%$ of the phytoplankton biomass. Presumably these nanoflagellates dominate the phytoplankton community during the stratified period until mixing again returns nutrients to the photic zone (Thomsen 1982)

The distribution of nutrients followed the structure of the water column, indicating that the bloom had been going on for some time. The classical way to evaluate Liebig nutrient limitation is to compare observed $P: N$ and $\mathrm{Si}$ N concentration ratios with the Redfield ratio, 16Si 15N:1P (by atoms) (Redfield 1958). P:N ratios $<1.16$ indicate $N$ limitation while $S i: N$ ratios below 1 indicate Si limitation, and ratios $>1$ indicate $N$ limitation. Of the 3 nutrients considered, phosphorus was present in excess throughout the study, as in Arctic waters in general (Harrison \& Cota 1991). The occurrence of nutrient depletion in the phytoplankton was supported by the 480:655 absorption ratios $>2$ associated with the surface water after the first 2 visits to the station (Fig. 3C). This indicates that the primary production in the last part of this investigation was supported by nutrients regenerated within the photic zone. Associated with the deepening and stabilization of the surface water, first nitrate and then silicate were depleted to below detection levels above the pycnocline (Fig. 2C, E). The temporal succession of the nutrient levels in the surface water could indicate that a shift from new to regenerated diatom production occurred until silicate became depleted from the surface and the diatoms sank out. After the nitrate was depleted from the surface, the diatoms presumably relied on remineralized nitrogen until silicate also became depleted. Silicon is to a great extent exported from the photic zone as diatom frustules in copepod faecal pellets. Because regeneration of silicon is much slower than nitrogen in the surface the diatom bloom left the photic zone when the silicon source became depleted.

\section{Importance of bacterial production and the microbial food web}

The high activity of the bacterioplankton during the spring bloom in Disko Bay is in contrast to the classical view (Table 2). The Arctic spring bloom dominated by large diatoms is expected to fuel a short classical food chain with copepods as the principal grazers, while a minor fraction of the primary production is channelled through the bacterioplankton and the microbial food web. During the present investigation, however, a well established and active bacterioplankton was observed from the first sampling day when the diatom bloom was present throughout the photic zone.

Two contradictory views exist on the role played by bacterioplankton in Arctic pelagic ecosystems. Studies in Newfoundland coastal waters suggest that the observed low bacterial response to a bloom of icealgae was caused by inhibition of bacterial production at low temperatures (Pomeroy \& Diebel 1986) or by a combination of temperature inhibition and substrate limitation (Pomeroy et al. 1990). However, in the Barents Sea, Thingstad \& Martinusson (1991), as in the present study, reported bacterial activity comparable to those of temperate ecosystems. Modelling Antarctic bacterioplankton dynamics suggests that relatively low bacterioplankton production is a response to the macromolecular nature of the DOC rather than to the low temperature (Billen \& Becquevort 1991).

Because high bacterial abundance and activity were observed from our first sampling, it was not possible to investigate the timing between the diatom bloom peak and the response by the bacterial population. Observations in the southern North Sea showed that the bacterial response lagged $2 \mathrm{wk}$ behind the culmination of the spring bloom (Lancelot \& Billen 1984, Billen \& Fontigny 1987). On the other hand, in the Barents Sea Thingstad \& Martinussen (1991) observed a bacterioplankton response before nitrate was depleted in the photic zone.

As the phytoplankton bloom progressed and nutrients were depleted, the bacterial biomass decreased, although the average bacterial production in the photic zone increased, probably in response to leakage from the nutrient depleted diatom cells (Table 3 ). This was even more pronounced if the water masses associated with the sedimenting bloom are taken into consideration (Fig. 3D). 
The temporal pattern in the bacterial biomass indicates that growth was roughly balanced by the loss processes, assuming that the main mortality of the bacterioplankton was due to grazing by bacterivorous heterotrophic nanoflagellates (HNAN) (Fenchel 1986). The abundance of HNAN in Disko Bay is comparable to the observations from the North Bering Sea, 0.5 to $1.3 \times 10^{3} \mathrm{ml}^{-1}$ (Andersen 1988). A calculation of the grazing pressure showed that the HNAN in Disko Bay are capable of clearing the daily bacterial production during the bloom (Fig. 11). But after the phytoplankton bloom, the increase in bacterial production was not followed by a response in the HNAN population. In temperate coastal waters a close coupling between bacterioplankton and HNAN has been shown (Andersen \& Fenchel 1985, Andersen \& Sørensen 1986). In the present study, no such correlation was evident, perhaps due to significant predation on the HNAN.

The most important consumers of the nanoplankton are the heterotrophic ciliates (Fenchel 1987). Several field studies have demonstrated a correlation between the growth rate of planktonic ciliates and their nanoplankton prey (e.g. Andersen \& Sørensen 1986,
Verity 1986). A well-established ciliate community dominated by naked oligotrich ciliates was present from the beginning of this study. The abundance and species composition of the Disko Bay ciliate community were within the same range and comparable to what is reported from Arctic Canada (Paranjape 1987. 1988), the North Bering Sea (Andersen 1988) and the Greenland Sea (Putt 1990), and not different from those found at lower latitudes (Taniguchi 1984, Pierce \& Turner 1992, Nielsen \& Kiørboe 1994). Our fixative (Lugol's) did not allow us to distinguish between heterotrophic and mixotrophic ciliates, but presumably a significant fraction of the ciliate community was comprised of chlorophyll-containing species as observed in the Greenland Sea (Putt 1990). The vertical distribution of the ciliates closely followed the phytoplankton, with the highest biomass located in association with the diatom bloom. The fractionation of the phytoplankton was chosen to separate potential food: for ciliates, $<11 \mu \mathrm{m}_{\mathrm{i}}$ and for copepods, $>11 \mu \mathrm{m}$. However, during the microscopic examination ciliates were often observed with small diatoms $(15$ to $20 \mu \mathrm{m})$ in their food vacuoles.
A
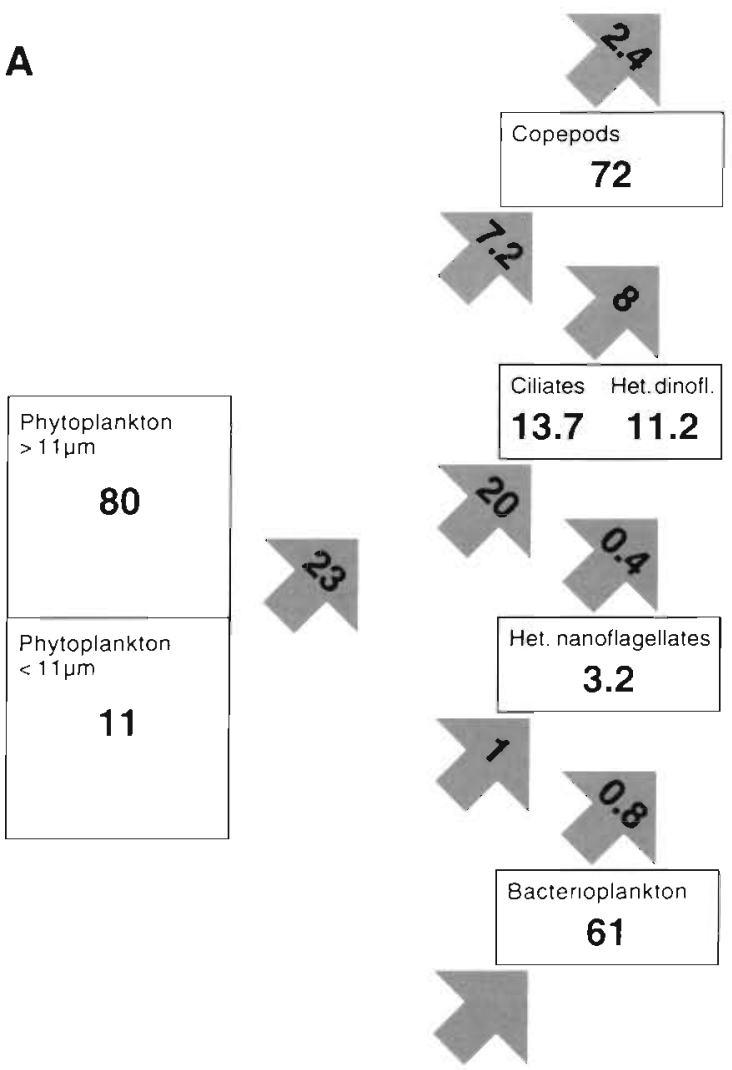

B

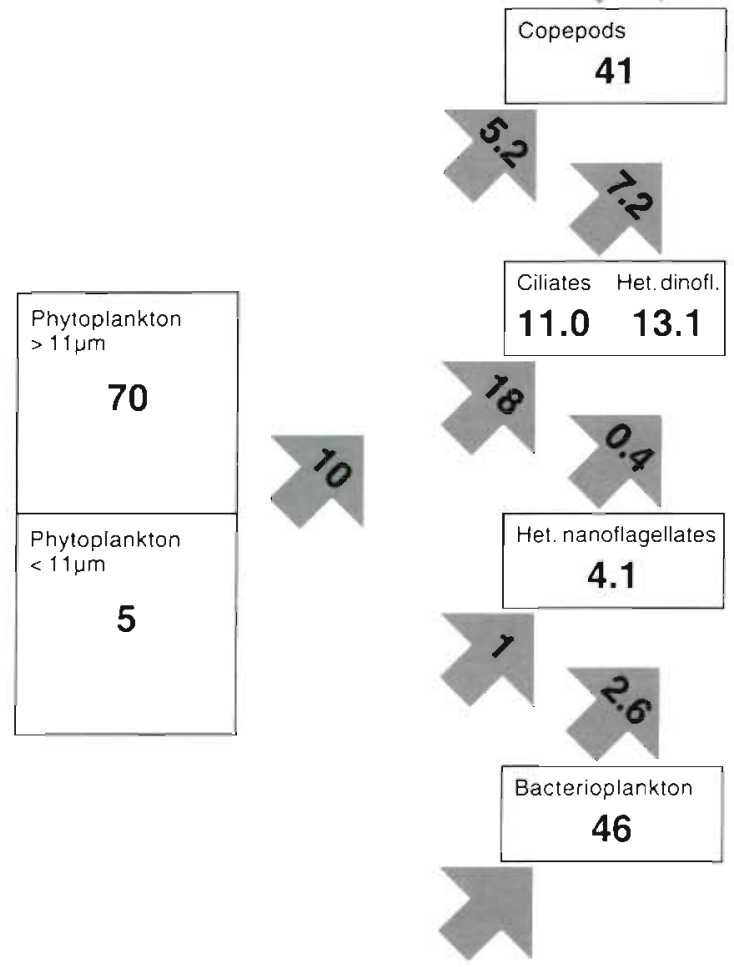

Fig. 11. Carbon flow budgets (A) before and (B) after sedimentation of a diatom bloom in Disko Bay. The figure is based on the data shown in Tables $3 \& 6$. Numbers in boxes show average biomass ( $\mathrm{mg} \mathrm{C}^{-3}$ ) and numbers on the arrows entering and leaving the boxes represent ingestion and production, respectively $\left(\mathrm{mg} C \mathrm{~m}^{-3} \mathrm{~d}^{-1}\right)$ 
Recent investigations have stressed the potential importance of the heterotrophic dinoflagellates in the plankton dynamics of temperate (Smetacek 1981, Hansen 1991, Verity et al. 1993), subtropical (Lessard 1991), and Antarctic waters (Bjornsen \& Kuparinen 1991). So far, heterotrophic dinoflagellates have received little attention in the Arctic. However, in Disko Bay the heterotrophic dinoflagellates accounted for about $50 \%$ of the protozooplankton biomass, with nanodinoflagellates comprising about half of the total dinoflagellate biomass (Table 3). High abundance of large dinoflagellates is often associated with blooms of diatoms (Smetacek 1981, Hansen 1991). The now widely accepted hypothesis of the microbial loop is based on the existence of a fixed size ratio between planktonic predators and their prey of 10:1 (Azam et al. 1983). However, recent investigation has questioned this assumption, because important groups such as the heterotrophic dinoflagellates can graze on very large prey items (Hansen et al. 1994b). The larger heterotrophic dinoflagellates $(>20 \mu \mathrm{m})$ were dominated by the naked Gyrodinium spirale (ESD 35 to $40 \mu \mathrm{m}$ ), with a prey size spectrum ranging from about $5 \mu \mathrm{m}$ ESD to particles up to 5 times its own cell volume (Hansen 1992). This wide prey size spectrum enables the dinoflagellates to exploit all the size classes of the phytoplankton present during this study.

Before and after the bloom left the photic zone 87 to $180 \%$ of the primary production was ingested by protozooplankton per day (Fig. 11). These grazing estimates are comparable to the few existing studies of the significance of Arctic microzooplankton. In a study of the quantitative importance of the microbial loop in the North Bering Sea, Andersen (1988) found that the ciliates grazed between 1 and $77 \%$ of the daily primary production. The highest grazing pressure was found at stations dominated by pico-nanoplankton and the lowest at diatom-dominated stations. During that study the impact of the heterotrophic dinoflagellates was not considered. Paranjape (1987) studied the grazing impact of the microzooplankton by the dilution method in Baffin Bay, in a situation where the phytoplankton was dominated by small diatoms as during the present study, and found daily grazing rates of 37 to $114 \%$ of the primary production. For temperate waters most of the estimates of microzooplankton grazing impact during the summer range from 40 to $>100 \%$ of the daily primary production (Pierce \& Turner 1992, Nielsen et al. 1993, Nielsen \& Kiørboe 1994). Thus the potential importance of protozooplankton in the Arctic pelagic food web is not different from that in low latitude ecosystems.

Planktonic ciliates potentially compete with the heterotrophic dinoflagellates for the primary producers as prey. However, the maximum prey size that naked and loricate oligotrichs can ingest is limited to about $45 \%$ of their oral diameter (Heinbokel 1978, Jonsson 1986). This suggests that the dominating Strombidium spp. and Lohmaniella spp. with an oral diameter of 40 to $50 \mu \mathrm{m}$ only exploited the nanoflagellates and the smaller diatoms $<20 \mu \mathrm{m}$. The implication of this is that the ciliates primarily compete with the nanodinoflagellates $(<20 \mu \mathrm{m})$ for food while the larger heterotrophic dinoflagellates compete with copepods for the large size classes of prey. Copepods, on the other hand, can exploit the microzooplankton (e.g. Barthel 1988, Ohman \& Runge 1994). However, as long as the diatom bloom lasted the copepod ingestion probably was saturated and the predation on the microzooplankton was low (Fessenden \& Cowles 1994, Nielsen \& Kiørboe 1994). Copepod grazing on protozooplankton has, to our knowledge, not been examined in polar systems but may represent a significant carbon source for the copepods, particularly after the spring bloom when small phytoplankton dominate.

\section{The copepods and the classical food chain}

The species composition of the copepod community in Disko Bay was as previously reported for Greenlandic waters with a dominance of Calanus spp. (Smidt 1979. Smith et al. 1985, Hirche et al. 1991). Sampling was conducted using a $200 \mu \mathrm{m}$ WP $\mu-2$ net, where a fraction of the smallest stages of Calanus spp. and the smallest species, e.g. Oithona spp., might have been lost through the mesh. However, additional casts with a small mesh net $(45 \mu \mathrm{m})$ and with water bottles did not show large abundances of small copepod species, so we assume that the major part of the copepod community was included in our samples.

The copepod stage composition, with increasing numbers of stages CI to II of Calanus finmarchicus and stage CIII of C. glacialis during June, and more advanced stages of $C$. hyperboreus present, agrees with Smidt (1979). It suggests growth and development of the 2 smallest Calanus species. Reproduction of C. finmarchicus and C. glacialis was synchronized with the development of the phytoplankton as illustrated by the correlation between the egg production and chlorophyll (Fig. 10). The spawning of C. hyperboreus was largely over during this study. This species spawns early in the spring in the absence of food, relying on fat reserves deposited the previous year (Conover 1967); however, more eggs are produced when food is present (Conover 1988).

The egg production of the Calanus spp. during June and July suggests decreasing productivity. This is supported by observations on maximum presence of eggs in March and nauplii in July in the Nuuk area (Smidt 
1979). Slagstad \& Tande (1990) reported initiation of egg production by $C$. glacialis in April in Arctic waters of the Barents Sea. The gonad maturation of the Calanus spp. in the Arctic Ocean showed that most of the mature specimens were associated with the upper $50 \mathrm{~m}$, and that specimens from deeper water were not capable of producing eggs (Hirche \& Mumm 1992). They also measured egg production close to zero for $C$. finmarchicus and 1 to 5 eggs $o^{-1} \mathrm{~d}^{-1}$ for C. glacialis in the Nansen Basin. They concluded that the limited egg production was a matter of long-term food depletion. In the Fram Strait, Hirche et al. (1991) measured egg production rates for $C$. finmarchicus and $C$. glacialis of 1 to 4 and 1 to 44 eggs $q^{-1} \mathrm{~d}^{-1}$, respectively. In the present study $C$. finmarchicus and $C$. glacialis produced more eggs and were certainly not limited by food. $C$. hyperboreus had passed the peak of egg production, and most of the ingestion was allocated to storage of lipids in the advanced copepodite stages. The smaller stages of copepodites, however, still experienced growth and stage shifts, most obviously for $C$. finmarchicus and C. glacialis

After the diatoms left the photic zone, the vertical distribution of the copepod biomass followed the biomass of the algae, with a relatively high fraction of the copepod biomass in the mid water (Fig. 7B). This observation is in agreement with studies of vertical distribution of copepods during spring and summer in other Arctic areas (Eilertsen et al. 1989, Hansen et al. 1990, Unstad \& Tande 1991).

The specimens situated in the deep waters always had empty guts as found by Bămstedt et al. (1990) and, therefore, did not contribute to the grazing in the photic zone. Smith (1988) and Hansen et al. (1990) showed that Arctic copepods did not undergo diel vertical migration during the summer in the Fram Strait and the Barents Sea but aggregated in the upper 25 to $50 \mathrm{~m}$ when feeding, while the individuals in the deep water probably were in a resting state. This is supported by Hircne (1989), who showed that the enzyme activity of the surface populations of Calanus spp. in the Greenland Sea was much higher than those in the deep water, stressing that this part of the population did not graze on the phytoplankton.

Even though the spawning of Calanus hyperboreus was over, this species continued to have a significant grazing impact on the phytoplankton in the photic zone (Tables $5 \& 6$ ). The high $C: N$ ratio of $C$ hyperboreus females, compared with the egg producing $C$. glacialis, suggests that the ingested carbon of $C$. hyperboreus was being allocated to building up lipid stores (Table 7).

Depending on the method used, the grazing impact by the copepod community was 45 or $92 \%$ and 43 or $80 \%$ of the daily primary production before and after the bloom left the photic zone, respectively (Table 6). This similarity in results for the 2 methods was also tound for Calanus finmarchicus by Kiørboe et al. (1985b) in the Kattegat/Skagerrak area. The copepod community grazing, estimated by the egg production method in the Fram Strait, never exceeded $50 \%$ of the daily primary production (Hirche et al. 1991). In the same area Smith et al. (1985) estimated the turnover time of phytoplankton standing stock caused by copepod grazing to be about $13 \mathrm{~d}$, which is on the same order of magnitude found during this investigation. This indicates that the copepod population alone cannot control the phytoplankton during the bloom. However, after the main bloom, investigations in the Polar Front of the Barents Sea (Hansen et al. 1990) and in the Canadian High Arctic (Longhurst \& Head 1989) have documented a grazing impact of the Calanus spp. that exceeds the daily primary production.

\section{Carbon budget and food web dynamics}

Even though the hydrography at the sampling site is dynamic and greatly influenced by advection caused by the outflow of surface water from the glacier Jakobshavn Isfjord (Fig, 1), we have established 2 scenarios and constructed carbon budgets based on the successional stage of the phytoplankton bloom: (1) before and (2) after the diatoms leave the photic zone (Fig. 11). We are aware of that the outcome of these carbon budgets is greatly influenced by the carbon:chl a ratio and by the carbon conversion factors for the plankton. However, we still believe that the carbon budget model is a good framework for summarizing and discussing the structure and dynamics of the ecosystem under consideration.

The ratio between the production and biomass of bacterio-and phytoplankton illustrates the importance of the 2 major carbon routes. During the bloom the relative importance of the bacterioplankton was low after which it increased as the bloom became nutrient depleted (Table 2). These ratios are significantly different from the low ratios of 0.5 to $5 \%$ reported from Arctic Canada by Pomeroy et al. (1990). A similar change in the relative importance of the carbon routes was observed during the transition from spring bloom to stratified conditions in the North Sea (Nielsen \& Richardson 1989, Nielsen et al. 1993).

The carbon budgets seem to balance during the bloom (Fig. 11A); the bacterial production can satisfy the carbon demand of the HNAN. However, HNAN production alone can only supply $2 \%$ of the microzooplankton carbon demand. If the primary producers are included as food for protozooplankton, the carbon requirement can be covered. The carbon needs of the 
copepods can be covered by production of the larger phytoplankton and the protozooplankton. After the bloom the ecosystem became more heterotrophic. The biomass and activity of the upper heterotrophic compartments of the food web were more or less the same, but the primary production decreased to about half and the bacterial production tripled compared with the bloom condition (Fig. 11B). At this stage, the bacterioplankton can still fulfil the carbon needs of the HNAN, but the carbon requirements of the succeeding links in the food web cannot be covered by the primary production, indicating that the grazers now reduce the standing stock of phytoplankton.

Just by comparing the standing stocks of meso- and protozooplankton the potential importance of the latter group becomes evident. The copepod biomass averaged $60 \pm 28 \mathrm{mg} \mathrm{C} \mathrm{m}^{-3}$ in the photic zone, while the protozooplankton, which had a much shorter expected turnover time, was equivalent to $41 \%$ of the mesozooplankton biomass. The importance of the protozooplankton is even more evident when the potential grazing impact is taken into consideration. The grazing impact of the protozooplankton was 2.8 and 3.5 times higher than that of the copepods during and after the bloom, respectively. In both situations the potential protozooplankton production alone could satisfy the carbon needs of the copepod community. This pathway may be even more important after the main bloom when the phytoplankton is dominated by smaller cells.

Normally, high protozooplankton grazing is expected in situations where the phytoplankton is dominated by small cells, and copepod grazing is expected in diatom situations. During the present study, however, protozooplankton grazing exceeded copepod grazing even though the phytoplankton was dominated by relatively large diatoms. In investigations during summer in the northeastern Atlantic Ocean (Burkill et al. 1993) and the North Sea (Nielsen et al. 1993), where copepods were expected to be the principal herbivores, it was also concluded that protozooplankton herbivory provided the major route for phytoplankton transfer to higher trophic levels.

The biomass and activity of the microbial food web relative to the Calanus-dominated mesozooplankton documented by this study illustrates the potential importance of bacterio- and protozooplankton in the pelagic food web. It shows that the carbon flow in an Arctic pelagic ecosystem may have the same complexity as those at lower latitudes.

Acknowledgements. We thank Christian Marc Andersen, Sten Christiansen, Dorete W. Jensen, Alexandra C. Nielsen, and Gitte Nielsen for technical assistance. We are grateful to the crew on RV 'Porsild' for help during sampling and to Copenhagen University, The Board of Arctic Station, for providing excellent facilities. We appreciate critical comments by
Jeffrey Runge, Kurt Tande and 3 anonymous reviewers on an earlier version of the manuscript. This investigation was supported by grants from Nordic Institute in Greenland grant no. 26667 and grant no. 11-8348 from the Danish Natural Science Council.

\section{LITERATURE CITED}

Andersen OGN (1981a) The annual cycle of temperature, salinity, currents and water masses in Disko Bugt and adjacent waters, West Greenland. Meddr Gronland 5: $1-33$

Andersen OGN (1981b) The annual cycle of phytoplankton primary production and hydrography in Disko Bugt area, West Greenland. Meddr Grønland 6:65

Andersen P (1988) The quantitative importance of the 'microbial loop' in the marine pelagic: a case study from the North Bering/Chukchi Sea. Arch Hydrobiol 31:243-251

Andersen P, Fenchel $T$ (1985) Bacterivory by microheterotrophic flagellates in seawater samples. Limnol Oceanogr 30:198-202

Andersen P, Sørensen HM (1986) Population dynamics and trophic coupling in pelagic microorganisms in eutrophic coastal waters. Mar Ecol Prog Ser 33:99-109

Azam F, Fenchel I, Field JG, Gray JS, Meyer-Reil LA, Thingstad $F$ (1983) The ecological role of water column microbes in the sea. Mar Ecol Prog Ser 10:257-263

Azam F, Smidt DC, Hollibaugh JT (1991) The role of the microbial loop in Antarctic pelagic ecosystems. Polar Res 10:239-243

Barthel KG (1988) Feeding of three Calanus species on different phytoplankton assemblages in the Greenland Sea. Meeresforsch 32:92-106

Berggreen U, Hansen B, Kiørboe K (1988) Food size spectra, ingestion and growth of the copepod Acartia tonsa during development: implications for determination of copepod production. Mar Biol 99:341-352

Billen G, Becquevort S (1991) Phytoplankton-bacteria relationships in the Antarctic marine ecosystem. Polar Res 10 : 245-253

Billen G, Fontigny A (1987) Dynamics of a Phaeocystis dominated spring bloom in Belgian coastal water Il. Bacterioplankton dynamics. Mar Ecol Prog Ser 37:249-257

Bjørnsen PK (1986) Automatized determination of bacterioplankton biomass by image analysis. Appl environ Microbiol 51:1199-1204

Bjørnsen PK, Kuparinen J (1991) Growth and herbivory by heterotrophic dinoflagellates in the Southern Ocean, studied by microcosm experiments. Mar Biol 109:397-405

Burkill PH, Edwards ES, John AWG, Sleigh MA (1993) Microzooplankton and their herbivorous activity in the Northeastern Atlantic Ocean. Deep Sea Res 40:479-493

Båmstedt U, Håkansson JL, Brenner-Larsen J, Bjernsen PK, Geertz-Hansen O, Tiselius P (1990) Copepod nutritional condition and pelagic production during autumn in Kosterfjorden, Western Sweden. Mar Biol 104:197-208

Conover RJ (1967) Reproductive cycle, early development, and fecundity in laboratory populations of the copepod Calanus hyperboreus. Crustaceana 13:61-72

Conover RJ (1988) Comparative life histories in the genera Calanus and Neocalanus in high latitudes of the northern hemisphere. Hydrobiologia 167/168:127-142

Dodge JD (1985) Marine dinoflagellates of the British Isles. Her Majesty's Stationary Office, London

Edler L (1979) Recommendations for marine biological studies in the Baltic sea. Baltic mar Biol Publ 5:1-38 
Eilertsen HC, Tande KS, Taasen JP (1989) Vertical distribution of pnmary production and grazing by Calanus glacialis Jaschnov and C. Hyperboreus Kroyer in Arctic waters (Barents Sea). Polar Biol 9:253-260

Fenchel $T$ (1986) The ecology of heterotrophic flagellates Adv microb Ecol 9:57-95

Fenchel T (1988) Microfauna in the planktonic food chain. In Blackburn TH, Sorensen J (eds) Nitrogen cycling in coastal marine environments. SCOPE, John Wiley \& Sons Ltd, p 59-65

Fessenden L, Cowles TJ (1994) Copepod predation on phagotrophic ciliates in Oregon coastal waters. Mar Ecol Prog Ser 107:103-111

Fuhrman J, Azam F (1980) Bacterioplankton secondary production estimates for coastal waters of British Colombia, Antarctica and California. Appl environ Microbiol 39(6): 1085-1095

Garrison DL, Buck KR, Growing MM (1993) Winter plankton assemblage in the ice edge zone of the Weddell and Scotia Seas: composition, biomass and spatial distribution. Deep Sea Res 40(2):311-338

Grashoff K (1976) Methods for seawater analysis. Weinheim, New York

Haas LW (1982) Improved epifluorescence microscopy for observing planktonic microorganisms. Annls Inst Oceanogr 58:261-266

Hansen B, Berggreen UC, Tande KS, Eilertsen HC (1990) Post-bloom grazing by Calanus glacialis, C. finmarchicus and $C$. hyperboreus in the region of the Polar Front, Barents Sea. Mar Biol 104:5-14

Hansen B, Bjornsen PK. Hansen PJ (1994b) The size ratio between planktonic predators and their prey. Limnol Oceanogr 39:395-403

Hansen B, Verity P, Falkenhaug I, Tande KS, Norrbin F (1994a) On the trophic fate of Phaeocystis pouchetii (Harriot). V. Trophic relationships between Phaeocystis and zooplankton: an assessment of methods and size dependence. J Plankton Res 16:487-511

Hansen PJ (1991) Quantitative importance and trophic role of heterotrophic dinoflagellates in a coastal pelagic food web. Mar Ecol Prog Ser 73:253-261

Hansen PJ (1992) Prey size selection, feeding rates and growth dynamics of heterotrophic dinoflagellates with special emphasis on Gyrodinium spirale. Mar Biol 114: $327-334$

Harrison PJ, Clifford PJ, Cochlan WP, Yin K, St. John MA, Thompson PA, Sibbald MJ. Albright LJ (1991) Nutrient and plankton dynamics in the Fraser River plume, Strait of Georgia, British Colombia. Mar Ecol Prog Ser 70:291-304

Harrison WG, Cota GF (1991) Primary production in polar waters: relation to nutrient availability. Polar Res 10(1): $87-104$

Heath M, Richardson K, Kiørboe $\Upsilon$ (1990) Optical assessment of phytoplankton nutrient depletion. J Plankton Res 12(2): $381-396$

Heinbokel JF (1978) Studies on the functional role of tintinnuds in the Southern California Bight II. Grazing rates of field populations. Mar Biol 47:191-197

Hirche HJ (1989) Spatial distribution of digestive enzymes activities of Calanus finmarchicus and C. hyperboreus in Fram Strait/Greenland Sea. J Plankton Res 11(3):431-443

Hirche HJ, Baumann MEM, Kattner G, Gradinger R (1991) Plankton distribution and the impact of copepod grazing on primary production in Fram Strait, Greenland Sea. J mar Syst 2:477-494

Hirche HJ, Mumm N (1992) Distribution of dominant copepods in the Nansen Basin, Arctic Ocean, in summer. Deep
Sea Res 39:485-505

Hobbie JE, Daley RJ, Jaspers S (1977) Use of nuclepore filters for counting bacteria by epifluorescence. Appl environ Microbiol 33:1255-1228

Huntley M, Tande $\mathrm{K}$, Eilertsen $\mathrm{HC}$ (1987) On the trophic fate of Phaeocystis pouchetii (Harriot). II. Grazing rates of Calanus hyperboreus (Krøyer) on diatoms and different size categories of Phaeocystis pouchetii. J exp mar Biol Ecol 110:197-212

Jespersen AM, Christoffersen K (1987) Measurements of chlorophyll-a from phytoplankton using ethanol as extraction solvent. Arch Hydrobiol 109:445-454

Jonsson PR (1986) Particle size selection, feeding rates and growth dynamics of marine planktonic oligotrichous ciliates (Ciliophora: Oligotrichina). Mar Ecol Prog Ser 33: $265-277$

Kahl A (1932) Urtiere oder protozoa. I. Wimpertiere oder Ciliata (Infusoria). 3. Spirotricha. In: Dahl F (ed) Die Tierwelt Deutschlands und der angrenzenden Meeresteile. Gustav Fishers Verlag, Jena

Kiorboe T, Møhlenberg F, Hamburger K (1985a) Bioenergetics of the planktonic copepod Acartia tonsa: relation between feeding, egg production and respiration, and composition of specific dynamic action. Mar Ecol Prog Ser 26:85-97

Kiørboe T, Møhlenberg F, Riisgaard HU (1985b) In situ feeding rates of planktonic copepods: a comparison of four methods. J exp mar Biol Ecol 88:67-81

Krylov VV (1968) Relation between wet formalin weight of copepods and copepod body length. USSR Acad Sci Oceanology 8:723-727

Kuosa H. Kivi K (1989) Bacteria and heterotrophic flagellates in the pelagic carbon cycle of the northern Baltic Sea. Mar Ecol Prog Ser 53:93-100

Lancelot C, Billen G (1984) Activity of heterotrophic bacteria and its coupling to primary production during spring phytoplankton bloom in the southern bight of the North Sea. Limnol Oceanogr 29:721-730

Leegaard C (1915) Untersuchungen über einige Planktonciliaten des Meeres. Nytt Mag Naturvidensk 53:1-37

Lessard EJ (1991) The trophic role of heterotrophic dinoflagellates in diverse marine environments. Mar microb Food Webs 5(1):49-58

Longhurst A, Head E (1989) Algal production and variable herbivore demand in Jones Sound, Canadian High Arctic. Polar Biol 9:281-286

Lynn DJ, Montagnes DJS, Small EB (1988) Taxonomic description of some conspicuous species in the family Strombidiidae (Ciliophora: Oligotrichida) from the Isles of Shoals, Gulf of Main. J mar biol Ass UK 62(2):252-259

Nielsen GE, Bresta AM (1984) Guidelines for measurements of phytoplankton primary production. Baltic mar Biol Publ $1: 1-23$

Nielsen TG, Kiørboe T (1994) Regulation of zooplankton biomass and production in a temperate, coastal ecosystem, 2 Ciliates. Limnol Oceanogr 39(3):508-519

Nielsen TG, Lokkegaard B, Richardson $\mathrm{K}$, Bo Pedersen $F_{1}$ Hansen L (1993) Structure of the plankton community in the Dogger Bank area (North Sea) during a stratified situation. Mar Ecol Prog Ser 95:115-131

Ohman MD, Runge JA (1994) Sustained fecundity when phytoplankton resources are in short supply: omnivory by Calanus finmarchicus in the Gulf of St. Lawrence. Limnol Oceanogr 39(1):21-36

Omori M (1969) Weight and chemical composition of some important oceanic zooplankton in the North Pacific Ocean. Mar Biol 3:4-10 
Paranjape MA (1987) Grazing by microzooplankton in the eastern Canadian Arctic in summer 1983. Mar Ecol Prog Ser 40:239-246

Paranjape MA (1988) Microzooplankton in Lancaster Sound (eastern Canadian Arctic) in summer: biomass and distribution. Deep Sea Res 35:1547-1563

Petersen GH (1964) The hydrography, primary production, bathymetry and 'Tagsâq' of Disko Bugt, West Greenland. Meddr Gronland 159:1-45

Peterson WT (1988) Rates of egg production by the copepod Calanus marshallae in the laboratory and in the sea off Oregon. Mar Ecol Prog Ser 47:229-237

Pierce RW, Turner J (1992) Ecology of planktonic ciliates in marine food webs. Rev aquat Sci 6(2):139-181

Pomeroy LR, Deibel D (1986) Temperature regulation of bacterial activity during the spring bloom in Newfoundland coastal waters. Science 233:359-361

Pomeroy LR, Macko SA, Ostrom PH, Dunphy J (1990) The microbial food web in arctic seawater: concentration of dissolved free amino acids and bacterial abundance and activity in the Arctic Ocean and in Resolute Passage. Mar Ecol Prog Ser 61:31-40

Putt M (1990) Abundance, chlorophyll content and photosynthetic rates of ciliates in the Nordic Seas during summer Deep Sea Res 37:1731-1731

Redfield AC (1958) The biological control of chemical factors in the environment. Am Scient 46:205-222

Richardson K (1991) Comparison of ${ }^{14} \mathrm{C}$ primary production determinations made by different laboratories. Mar Ecol Prog Ser 72:189-201

Riemann B, Bjørnsen PK, Newell S, Fallon R (1987) Calculation of cell production of coastal marine bacteria based on measured incorporation of ${ }^{3} \mathrm{H}$-thymidine. Limnol Oceanogr 32:471-476

Robertson A (1968) The continuous plankton recorder: a method for studying the biomass of calanoid copepods. Bull mar Ecol 6:185-237

Slagstad D. Tande KS (1990) Growth and production dynamics of Calanus glacialis in an arctic pelagic food web. Mar Ecol Prog Ser 63:189-199

Smetacek V (1981) The annual cycle of protozooplankton in the Kiel Bight. Mar Biol 63:1-11

Smidt ELB (1979) Annual cycles of primary production and of zooplankton at Southwest Greenland. Meddr Grønland 1 $1-52$

This article was submitted to the editor
Smith SL (1988) Copepods in the Fram Strait in summer: distribution, feeding and metabolism. J mar Res 46:145-181

Smith WO, Sakshaug E (1990) Polar phytoplankton. In: Smith WO (ed) Polar oceanography, Part B. Chemistry, biology and geology. Academic Press, Inc, San Diego, p 477-525

Smith SL, Schnack-Schiel SB (1990) Polar zooplankton. In Smith WO (ed) Polar oceanography, Part B. Chemistry, biology and geology. Academic Press, Inc, San Diego, p 527-598

Smith SL, Smith WO, Codispoti LA, Wilson DL (1985) Biological observations in the marginal ice zone of the East Greenland Sea. J mar Res 43:693-717

Steemann Nielsen E (1958) A survey of recent Danish measurements of the organic productivity in the sea. Rapp P-v Reun Cons Perm int Explor Mer 144:92-95

Strickland JDH, Parsons TR (1968) A practical handbook of seawater analysis. Bull Fish Res Bd Can 167:1-310

Tande KS (1991) Calanus in North Norwegian fjords and in the Barent Sea. Polar Res 10:389-407

Taniguchi A (1984) Microzooplankton biomass in the Arctic and Subarctic Pacific Ocean in summer. Memoirs of the National Institute of Polar Research, Proc 6th Symp polar Biol, Spec Iss 32:63-76

Thingstad TF, Martinussen I (1991) Are bacteria active in the cold pelagic ecosystem of the Barents Sea? Polar Res 10: 255-265

Thomsen HA. (1982) Planktonic choanoflagellates from Disko Bugt, West Greenland, with a survey of the marine nanoplankton of the area. Meddr Gronland 8:1-35

Unstad KH, Tande KS (1991) Depth distribution of Calanus finmarchicus and $C$. glacialis in relation to environmental conditions in the Barents Sea. Polar Res 10:409-421

Vadstein O, Harkjerr BO, Jensen A. (1989) Cycling of organic carbon in the photic zone of a eutrophic lake with special reference to the heterotrophic bacteria. Limnol Oceanogr 34:840-855

Verity PG (1986) Growth rates of natural tintinnid populations in Narragansett Bay. Mar Ecol Prog Ser 29:117-126

Verity PG, Stoecker DK, Sieracki ME, Burkill PH, Edwards ES, Tronzo CR (1993) Abundance, biomass and distribution of heterotrophic dinoflagellates during the North Atlantic spring bloom. Deep Sea Res II 40(I/II):227-244

Wang R, Conover RJ (1986) Dynamics of gut pigment in the copepod Temora longicornis and the determination of in situ grazing rates. Limnol Oceanogr 31:867-877

Manuscript first received: October 21, 1994

Revised version accepted: March 20, 1995 